\title{
Particles' phase state variability in the North Atlantic free troposphere during summertime determined by different atmospheric transport patterns and sources
}

Zezhen Cheng ${ }^{1}$, Megan Morgenstern ${ }^{2}$, Bo Zhang ${ }^{3}$, Matthew Fraund ${ }^{4}$, Nurun Nahar Lata ${ }^{1}$, Rhenton

5 Brimberry $^{1}$, Matthew A. Marcus ${ }^{4}$, Lynn Mazzoleni ${ }^{2}$, Paulo Fialho ${ }^{5}$, Silvia Henning ${ }^{6}$, Birgit Wehner ${ }^{6}$, Claudio Mazzoleni ${ }^{2}$, Swarup China ${ }^{1}$

${ }^{1}$ Environmental Molecular Sciences Laboratory, Pacific Northwest National Laboratory (PNNL),

Richland, Washington 99352, USA

${ }^{2}$ Atmospheric Sciences Program, Michigan Technological University, Houghton, Michigan, 49921, USA

$10 \quad{ }^{3}$ National Institute of Aerospace, Hampton, VA 23666, USA

${ }^{4}$ Advanced Light Source, Lawrence Berkeley National Laboratory, Berkeley, CA 94720, USA

${ }^{5}$ Institute of Volcanology and Risk Assessment - IVAR, Rua da Mãe de Deus, 9500-321 Ponta Delgada, Portugal

${ }^{6}$ Leibniz Institute for Tropospheric Research, Permoserstraße 15, 04318 Leipzig, Germany

Correspondence to: Swarup China (Swarup.china@pnnl.gov)

15 Abstract. Free tropospheric aerosol particles have important but poorly constrained climate effects due to transformations of their physicochemical properties during long-range transport. In this study, we investigated the chemical composition and provided an overview of the phase state of individual particles that have been long-range transported over the North Atlantic Ocean in June and July 2014, 2015, and 2017 to the Observatory of Mount Pico (OMP), in the Azores. OMP is an ideal site for studying long-range transported free tropospheric particles with negligible influence from local emissions and rare

20 contributions from the boundary layer. We used the FLEXible PARTicle Lagrangian particle dispersion model (FLEXPART) to determine the origin and transport trajectories of sampled air masses and found that most originated from North America and recirculated over the North Atlantic Ocean. The FLEXPART analysis show that the sampled air masses were highly aged (average plume age $>10$ days). Size-resolved chemical compositions of individual particles were probed using computercontrolled scanning electron microscopy with an energy dispersive X-ray spectrometer (CCSEM-EDX) and scanning 25 transmission X-ray microscopy with near-edge X-ray absorption fine structure spectroscopy (STXM-NEXAFS). CCSEMEDX results show that the most abundant particle types were carbonaceous ( 29.9 to $82.0 \%$ ), sea salt $(\sim 0.3$ to $31.6 \%)$, and sea salt with sulfate ( 2.4 to $31.5 \%$ ). We used a tilted stage interfaced within an Environmental Scanning Electron Microscope (ESEM) to determine the phase state of individual submicron particles. We found that most particles ( 47 to $99 \%)$ were in the liquid state at the time of collection due to inorganic inclusions. Moreover, we also observed a substantial fraction of solid 
30 and semisolid particles ( $\sim 0$ to $30 \%$ and $\sim 1$ to $42 \%$, respectively) during different transport patterns/events, reflecting the particles' phase state variability for different atmospheric transport events and sources. Combining phase state measurements with FLEXPART CO tracer analysis, we found that wildfire-influenced plumes can result in particles with a wide range of viscosities after long-range transport in the free troposphere. We also used temperature and RH values extracted from the Global Forecast System (GFS) along the FLEXPART simulated path to predict the phase state of the particles during transport

35 and found that neglecting internal mixing with inorganics would overestimate the viscosity of free tropospheric particles. Our findings warrant future investigation on the quantitative assessment of the influence of internal mixing on the phase state of the individual particles. This study also provides insights into the chemical composition and phase state of free tropospheric particles, which can benefit models to reduce uncertainties in ambient aerosol particles' effects on climate.

40 Short summary. We observed a high abundance of liquid and internally mixed particles in samples collected in the North Atlantic free troposphere during summer. We also found several solid and semisolid particles for different emission sources and transport patterns. Our results suggest that considering the mixing state, emission source, and transport patterns of particles is necessary to estimate their phase state in the free troposphere, which is critical for predicting their effects on climate.

\section{Introduction}

45 Atmospheric aerosol particles play a vital role in regional and global climates. They influence climate by interacting with solar and terrestrial radiation and by interacting with clouds when acting as cloud droplet condensation and heterogeneous ice nuclei (Bellouin et al., 2020; Bond et al., 2013; Fan et al., 2016; Laskin et al., 2015; Moosmüller et al., 2009; Saleh, 2020). The efficiency of atmospheric particles to act as cloud droplets or ice nuclei strongly depends on their chemical composition and physical properties (Fan et al., 2016; IPCC, 2013; Seinfeld et al., 2016). However, the current understanding of atmospheric

50 aerosols' climate effects is still limited. One reason for such a gap in our understanding is that atmospheric aerosols have a wide range of viscosities and exhibit different phase states (e.g., solid (viscosity $>10^{12} \mathrm{~Pa} \mathrm{~s}$ ), semisolid $\left(10^{2}\right.$ to $10^{12} \mathrm{~Pa} \mathrm{~s}$ ), and liquid $\left(<10^{2} \mathrm{~Pa}\right.$ s)) (Reid et al., 2018; Virtanen et al., 2010, 2011). The viscosity affects the ability of the particle to participate in several important atmospheric processes such as cloud condensation (Hodas et al., 2015; Liu et al., 2018b), heterogeneous ice nucleation (more viscous/solid particle can promote ice formation) (Berkemeier et al., 2014; Knopf et al., 2018; Murray et

55 al., 2010; Reid et al., 2018; Sharma et al., 2018), and atmospheric aging process (e.g., higher viscosity reduces atmospheric reactivity and therefore slows aging) (Berkemeier et al., 2016; Kuwata and Martin, 2012; Liu et al., 2018a; Marshall et al., 2016; Pöschl and Shiraiwa, 2015a; Renbaum-Wolff et al., 2013). Several studies have found that the viscosity of atmospheric aerosols is affected by factors such as emission source, formation mechanism, material properties, chemical compositions, and ambient conditions (Koop et al., 2011; Li et al., 2020; Shiraiwa et al., 2017; Shrivastava et al., 2017; Virtanen et al., 2010).

60 Several studies have focused on the viscosity and/or phase state of atmospherically relevant submicron-sized particles (Bateman et al., 2014, 2015; Hosny et al., 2016; Jain and Petrucci, 2015; Li et al., 2017; Pajunoja et al., 2016; Renbaum-Wolff 
et al., 2013; Virtanen et al., 2010), but only a few studies reported field measurements of the phase state of ambient particles (Bateman et al., 2016, 2017; Liu et al., 2017, 2019; Pajunoja et al., 2016; Slade et al., 2019), and even more sparse are studies of aerosol phase state at high-altitude in the Free Troposphere (FT). This data gap is due to limitations in the measurement

65 techniques. Such limitations stem from the low particle concentrations at remote sites, particle sizes beyond the instrument's detection range, and challenges in directly measuring the phase state of individual particles. These drawbacks can be addressed by collecting aerosols on substrates and applying offline aerosol phase state analysis. One example of such analysis is using tilted SEM imaging to determine the phase state of particles based on the shape they acquire upon impaction on the substrate. In fact, solid, semisolid, and liquid organic particles will deform to near spheric, dome-like, and flat shapes, respectively, when

70 they impact on the substrates (Cheng et al., 2021; Reid et al., 2018; Sharma et al., 2018; Wang et al., 2016). Based on this approach, we applied a new analytical platform that uses tilted Scanning Electron Microscope (SEM) imaging to directly observe and assess the phase state of particles based on their shape deformation on the substrate (Cheng et al., 2021).

The FT is the atmospheric layer that extends above the planetary boundary layer (PBL), from about $1 \mathrm{~km}$ altitude to the

75 tropopause (Seinfeld and Pandis, 2006). Particles are injected in the FT mainly through convection and frontal uplift or are formed by oxidation of precursor gases (North et al., 2014). In turn, FT aerosols can be transported to the PBL via entrainment (De Wekker and Kossmann, 2015), dry deposition (Zufall and Davidson, 1998), and dry intrusions, which are events in which cold, dry air rapidly descends from the FT down to the PBL (Ilotoviz et al., 2021; Raveh-Rubin, 2017; Raveh-Rubin and Catto, 2019; Tomlin et al., 2021). The chemical composition of FT aerosols is complex (Bondy et al., 2018; Cozic et al., 2008;

80 Dzepina et al., 2015; Schum et al., 2018; Zhou et al., 2019) and continuously evolves since FT aerosols typically have longer lifetimes and are transported over long distances before reaching remote locations (Cozic et al., 2008; Gogoi et al., 2014; Haywood and Boucher, 2000; Huang et al., 2008). Thus, FT aerosols have longer atmospheric aging times to experience more physical interactions and chemical reactions with other atmospheric components, leading to more complex physical and chemical properties (Dunlea et al., 2009; Gogoi et al., 2014; Huang et al., 2008; Jaffe et al., 2005; Laing et al., 2016; Sun et

85 al., 2009; Zhou et al., 2019). Several previous studies focused on FT aerosols at remote sites, improving our understanding of regional and long-range transported aerosols (Boose et al., 2016; China et al., 2015, 2017; Clarke et al., 2013; Dzepina et al., 2015; Rinaldi et al., 2015; Rose et al., 2017; Schum et al., 2018; Zhou et al., 2019). For instance, Dzepina et al., 2015 conducted a study at the Observatory of Mount Pico (OMP) during the summer of 2012, and they found that FT aerosols underwent atmospheric oxidation such as photooxidation and aqueous-phase reactions (e.g., cloud processing) during the long-range 90 transport, and evaluated their chemical and physical properties. Moreover, Zhou et al., 2019 reported that organic aerosols in the FT were more oxidized and less volatile than those in the boundary layer, based on a study at the Mount Bachelor Observatory. Similarly, after analyzing samples collected at OMP during summertime, Schum et al., 2018 found that FT organic aerosols might be more viscous than PBL aerosols due to lower ambient temperature and relative humidity (RH) values, suggesting that FT organic aerosols might be less reactive than PBL organic particles. FT aerosols also indirectly affect climate by changing clouds albedo since they can act as cloud condensation nuclei (CCN) and ice nucleating particles (INP) 
(China et al., 2017; Clarke et al., 2013; Rose et al., 2017), and their chemical composition, particle size, mixing state, and phase state can affect their roles as CCN and INP (Ching et al., 2017; King et al., 2012; Knopf et al., 2018; Murray et al., 2010; Riemer et al., 2019; Schmale et al., 2017; Wang et al., 2010). Therefore, a better understanding of FT aerosols' chemical composition and phase state would improve the estimation of aerosol climate effects in current models. In this study, we focus on the chemical composition and phase state of FT aerosol and their correlation.

High-altitude mountaintop observatories are often used to study FT particles and atmospheric chemistry with advantages with respect to airborne field studies such as lower costs and long-term continuous measurements (Zhou et al., 2019). Various mountaintop sites are operating all over the world to investigate properties of FT aerosols and trace gases such as the High Altitude Research Station Jungfraujoch, Switzerland (Bianchi et al., 2016; Boose et al., 2016; Cozic et al., 2008; Motos et al., 2020), Mt. Cimone station in Italy (Fischer et al., 2003; Marinoni et al., 2008; Rinaldi et al., 2015), Mount Bachelor Observatory in central Oregon, US (Briggs et al., 2016; Weiss-Penzias et al., 2006; Zhou et al., 2019), and the OMP in the North Atlantic Ocean (Dzepina et al., 2015; Val Martin et al., 2008b). Along with these sites, the OMP is an ideal site for studying long-range transported FT aerosols from North America to Europe with negligible contribution from local sources

110 (Val Martin et al., 2008b, 2008a) and is one of the sites that is least influenced by the PBL (Coen et al., 2018). OMP is located in the summit caldera of the Pico Volcano (2225 m above sea level) on Pico Island in the Azores archipelago in the North Atlantic. The influence of local emission and marine boundary layer during summer on the air masses sampled at the site are typically negligible, making OMP an excellent location for long-range transported FT particles above the North Atlantic Ocean (Schum et al., 2018).

In this study, we present an overview of the phase state of individual FT atmospheric aerosol particles collected at OMP over three different years, which are July of 2014 (Pico 2014), and June and July of 2015 (Pico 2015) and 2017 (Pico 2017). The chemical composition and phase state of individual particles for Pico 2014 have been reported in a previous study (Lata et al., 2021). This study focuses on detailed individual particle analysis on Pico 2017. We performed FLEXible PARTicle Lagrangian

120 particle dispersion model (FLEXPART) simulations to select specific events to retrieve the origin of sampled air masses, transport trajectories, atmospheric aging time, and temperature and relative humidity in the air masses along the transport path. We applied multi-modal micro-spectroscopy techniques to probe aged and long-range transported particles' chemical composition and phase state. This study highlights how FT particles' phase state varies during different atmospheric transport events by combining probabilistic FLEXPART back trajectory analysis. 


\subsection{Sampling site and sample collection}

Samples of atmospheric particles were collected at the Observatory of Mount Pico (OMP), which is located in the summit caldera of the Pico Volcano (at $2225 \mathrm{~m}$ above sea level, $38.47^{\circ} \mathrm{N}, 28.40^{\circ} \mathrm{W}$ ) in the Azores, Portugal (Dzepina et al., 2015; Honrath et al., 2004; Val Martin et al., 2008b). Pico 2014 and Pico 2015 samples were collected during July 2014 and June

130 and July 2015 at OMP, and details of sampling times and conditions are listed in Table S1. Pico 2017 samples were collected during June and July 2017, and Table S2 reports the sampling times and environmental conditions. Additional experimental details are provided in the supporting information. Sample collection and storage for three years Pico samples followed the same protocol. All samples were collected on TEM B-film grids (300 mesh, Ted Pella, Inc) and lacey formvar grids (300 mesh, Ted Pella, Inc.) using a four-stage cascade impactor (MPS-4G1) at a flow rate of $\sim 7 \mathrm{lpm}$ for multi-modal micro-spectroscopy analysis. Particles were collected on the third and/or fourth stages of the impactor with $50 \%$ cutoff aerodynamic diameters of $>0.15 \mu \mathrm{m}$ and $>0.05 \mu \mathrm{m}$, respectively. Samples were stored in dry condition and wrapped in Al foil immediately after collection to avoid exposure to light and minimize potential modification and oxidation in air. Moreover, from 05 July 2017 to 21 July 2017, we also deployed a Scanning Mobility Particle Sizer (SMPS) to monitor the particle size distribution and the total particle concentration (Siebert et al., 2021).

\subsection{Origin of sampled air masses using FLEXPART}

The FLEXible PARTicle Lagrangian particle dispersion model (FLEXPART) was used to determine the origin of sampled air masses and their transport trajectories to OMP (Owen and Honrath, 2009; Seibert and Frank, 2004; Stohl et al., 2005). FLEXPART backward simulations were driven by meteorology fields of the Global Forecast System (GFS) featured with 3hourly temporal resolution, $1^{\circ}$ horizontal resolution, and 26 vertical levels. The output was saved in a grid with a horizontal

145 resolution of $1^{\circ}$ latitude by $1^{\circ}$ longitude and eleven vertical levels from the surface to $15,000 \mathrm{~m}$ a.s.l. More details of the model configurations can be found in (Zhang et al., 2014, 2017). FLEXPART simulated the spatial distribution of upwind residence time of the observed air masses. Transport trajectories (also called a "retroplume") of air masses were obtained by integrating the matrices of residence time over time and altitudes. We calculated a FLEXPART CO tracer by multiplying FLEXPART residence time with CO emission inventories from the Emissions Database for Global Atmospheric Research (EDGAR version

1503.2 (Olivier and Berdowski, 2001)) and the Global Fire Assimilation System (Kaiser et al., 2012) to estimate influence from anthropogenic and wildfire sources, respectively (Dzepina et al., 2015). We also extracted ambient temperature and relative humidity along the FLEXPART simulated transport pathways by sampling meteorological conditions in the GFS fields for each aerosol sample. The ambient temperature and relative humidity were used to estimate the aerosol phase state during transport (Schum et al., 2018). 
The particles collected from OMP were analyzed with a scanning transmission X-ray microscopy with near-edge X-ray absorption fine structure spectroscopy (STXM-NEXAFS) and a computer-controlled scanning electron microscopy with energy dispersive X-ray spectroscopy (CCSEM-EDX) to probe their physicochemical properties (Laskin et al., 2005, 2006). We utilized an environmental SEM (ESEM) equipped with a FEI Quanta digital field emission gun, operated at $20 \mathrm{kV}$ and

$160480 \mathrm{pA}$. Ambient particle samples were analyzed with ESEM at $293 \mathrm{~K}$ and under vacuum conditions $\left(\sim 2 \times 10^{-6}\right.$ Torr $)$, which would evaporate highly volatile compounds. ESEM images were used to retrieve individual particles' shape, morphology, and projected size (area equivalent diameter). The CCSEM, equipped with an EDX spectrometer (EDAX, Inc.), and the EDX spectra of individual particles were used to determine the chemical composition of the particles by quantifying the relative atomic ratios of 15 elements (C, N, O, Na, Mg, Al, Si, P, S, Cl, K, Ca, Mn, Fe, Zn). Since the EDX analysis of light elements such as $\mathrm{C}, \mathrm{N}$, and $\mathrm{O}$ is considered semi-quantitative and there are $\mathrm{C}$ and $\mathrm{O}$ contributions from the B-film substrate, we performed post-correction on the elemental percentage of $\mathrm{C}, \mathrm{N}$, and $\mathrm{O}$ (see SI). The corrected average atomic fractions of 15 elements of all samples are shown in Fig. S2. As shown in Fig. S2, all samples are dominated by C, N, and O (average atomic percentage of $\mathrm{C}, \mathrm{N}$, and $\mathrm{O}$ for each sample are 51.3 to $88.6 \%, 0.6$ to $22.0 \%, 7.5$ to $27.9 \%$, respectively), and the microscopy images show a minor fraction of soot particles, suggesting most particles are organic-rich. Based on their atomic ratio, each particle in Pico 2017 can be classified as organic carbonaceous (OC), carbonaceous with nitrogen (CNO), carbonaceous with sulfate (CNOS), sea salt (Na-rich), sea salt with sulfate (Na-rich with $\mathrm{S}$ ), dust (Al, Si, Ca, Fe), dust with sulfate (Al, Si, Ca, Fe, S), and others (see Fig. S3). CCSEM-EDX based particle classification for Pico 2014 can be found in Lata et al., 2021, and that for Pico 2015 will be discussed in our future work.

175 We used the STXM-NEXAFS spectroscopy at beamline 5.3.2.2 of the Advanced Light Source (ALS) at the Lawrence Berkley National Laboratory to probe the chemical bonding of carbon functional groups of individual particles. Due to beamline time constraints for STXM analysis, we focused only on selected samples and limited particles (653 for SA1, 208 for SA2, and 425 for SA3 for Pico 2014, 87 for S3 and 37 for S5 for Pico 2015, and 142 and 171 particles for S3-3 and S4-2 for Pico 2017). STXM uses a focused monochromatic soft X-ray beam generated from the synchrotron light source using a zone plate with 25

$180 \mathrm{~nm}$ outer zones. The sample is rastered under the beam, and the transmitted intensity is recorded to create an image. Spectroscopy is done by repeating this process at 111 energies to create a 'stack', in which each pixel contains a transmission spectrum. (Moffet et al., 2011). STXM-NEXAFS data was also used to calculate the total carbon absorbance (TCA) and the organic volume fraction (OVF). TCA at each pixel was calculated according to Eq. (1):

$\mathrm{TCA}=\mathrm{OD}_{320}-\mathrm{OD}_{278}$

185 where $\mathrm{OD}_{320}$ and $\mathrm{OD}_{278}$ are the optical density $(\mathrm{OD})$ of post- $(320 \mathrm{eV})$ and the pre- $(278 \mathrm{eV})$ carbon K-edge, respectively, and the TCA of individual particles was calculated as an average over each particle (O’Brien et al., 2014). Since OD was calculated as: 
$\mathrm{OD}=-\ln \left(I / I_{0}\right)=\mu \rho t$,

Where $I_{0}$ is the incident X-rays radiation intensity, $I$ is the transmitted intensity, $\mu$ is the mass absorption coefficient $\left(\mathrm{cm}^{2} \mathrm{~g}^{-1}\right)$, $\rho$ is the density $\left(\mathrm{g} \mathrm{cm}^{-3}\right)$, and $t$ is the thickness of the particle $(\mathrm{cm})$. Thus, TCA is proportional to and can be used as an indicator of particle thickness (O’Brien et al., 2014; Tomlin et al., 2020). The OVF was calculated based on a previously published method (Fraund et al., 2019). Briefly, we assume that each pixel in a particle is a mixture of elemental carbon (EC), organic (OC), and inorganic components (In). Thus, the OVF at each pixel can be calculated as the ratio of the thickness of the organic components $\left(t_{\mathrm{OC}}\right)$ divided by the total thickness of that pixel $\left(t_{\mathrm{OC}}+t_{\mathrm{In}}+t_{\mathrm{EC}}\right)$, and the OVF of each particle is the average over the different pixels within each particle (Fraund et al., 2019; Moffet et al., 2010; Pham et al., 2017). Based on Eq. 2, OD at preand post- edge and the $\mathrm{sp}^{2}$ peak $(285.4 \mathrm{eV})$ were used to calculate the thickness of OC, In, and EC, respectively (Fraund et al., 2019). Due to the variability of the $\mu$ and $\rho$ values for the different organic and inorganic components, we used $\left(\mathrm{NH}_{4}\right)_{2} \mathrm{SO}_{4}$ as a surrogate for the inorganic components of the particles based on the particles' average elemental composition retrieved from CCSEM-EDX measurements (see Sect. 3.3.1), and oxalic acid $\left(\mathrm{C}_{2} \mathrm{H}_{2} \mathrm{O}_{4}\right)$ as a surrogate for the organic components since oxalic acid has been shown to be abundant in ambient organic particles and has a representative oxygen-to-carbon ratio similar enough to ambient organic particles' (Fraund et al., 2019; Sorooshian et al., 2006; Yamasoe et al., 2000).

In addition, OD values at four critical energies (Pre-edge, $\mathrm{sp}^{2},-\mathrm{COOH}(288.5 \mathrm{eV})$, and post-edge) acquired from STXM spectra were used to classify regions in an individual particle as $\mathrm{OC}\left(\mathrm{OD}_{288.5}-\mathrm{OD}_{278}>0\right)$, In $\left(\mathrm{OD}_{278} / \mathrm{OD}_{320}>0.5\right)$, and $\mathrm{EC}\left(\mathrm{OD}_{285.4}\right.$ $\left./\left(\mathrm{OD}_{320}-\mathrm{OD}_{278}\right)>0.35\right)$ based on a previously published method (Fraund et al., 2019; Moffet et al., 2010, 2013). We classified each particle into 6 typical classes based on the volume fraction of OC, EC, and In components: 1) OC (OC is greater than 96 $\%$ and both EC and In are less than $2 \%$ ); 2) EC (EC is greater than $96 \%$ and both OC and In are less than $2 \%$ ); 3 ) In (In is greater than $96 \%$ and both OC and EC are less than $2 \%$ ); 4) OCEC (both OC and EC are greater than $2 \%$, and In is less than $2 \%$ ); 5) OCIn (both OC and inorganic are greater than $2 \%$, and EC is less than $2 \%$ ); and 6) OCInEC (OC, EC, and inorganics 210 are all greater than $2 \%$ ).

\subsection{Tilted imaging}

We utilized tilted view imaging combined with Environmental Scanning Electron Microscopy (ESEM, Quanta 3D, Thermo Fisher) to estimate the phase state of particles based on their shapes. For each sample, we evaluated more than 150 randomly selected particles. Typically, the shapes of solid, semisolid, and liquid organic particles are near spherical, dome-like, and flat,

215 respectively, when they impact on the surface of a substrate (Reid et al., 2018). For organic materials with solid inorganics (e.g., dust, soot, and salt) inclusion, the particle shape might be irregular and not follow the corrected aspect ratio threshold we proposed for organics (Cheng et al., 2021). Therefore, this study investigates only the phase state of organic particles that are not irregular in shape. To quantitatively assess the phase state of particles, we use the particles' corrected aspect ratio (corrected particle width/height ratio $\left(\mathrm{W}_{\text {corrected }} / \mathrm{H}_{\text {corrected }}\right)$ ) retrieved from tilted SEM images. A higher aspect ratio means that the particle 

2018; Wang et al., 2016). In this study, we used the same method introduced in Cheng et al., 2021 to retrieve the corrected aspect ratio of the particles. Briefly, we first calculated the tilted aspect ratio using the maximum particle length in the horizontal and vertical direction in the tilted SEM images ( $\mathrm{W}_{\text {tilted }}$ and $\mathrm{H}_{\text {tilted }}$, respectively) at a tilted view angle of $75^{\circ}$ (tilted aspect ratio $\left.=\left(\mathrm{W}_{\text {tilted }} / \mathrm{H}_{\text {tilted }}\right)\right)$; where $\mathrm{H}_{\text {tilted }}$ is the projection of the arc from top to base on the horizontal plane, and $\mathrm{W}_{\text {tilted }}$ is the

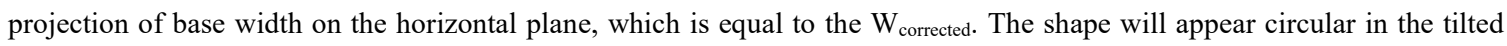

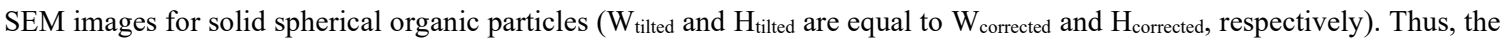
tilted aspect ratio is equal to the corrected aspect ratio for solid spherical particles. However, the shapes of semisolid and liquid organic particles will be distorted in the vertical direction $\left(\mathrm{W}_{\text {tilted }}=\mathrm{W}_{\text {corrected, }}\right.$, but $\left.\mathrm{H}_{\text {tilted }}>\mathrm{H}_{\text {corrected }}\right)$. When the particle is extremely flat (liquid state and very low viscosity), the $\mathrm{H}_{\text {tilted }}$ is the projection of the vertical diameter of the base on the horizontal plane.

230 Thus, in this case, the measured tilted aspect ratio is greater than or equal to $1 / \cos ($ tilt angle) $(=3.86$ in this study). Therefore, we consider any particles with a measured aspect ratio from tilted SEM images greater than 3.86 as biased, and we forced them to 3.86 due to the extremely flat shape of particles. To retrieve the correct aspect ratio of semisolid and solid particles, we applied the same conversion on tilted aspect ratios suggested by Cheng et al., 2021 if tilted aspect ratios were greater than 1.3. Thus, all aspect ratio discussed throughout this manuscript is the corrected aspect ratio. Then, we applied previously

235 proposed corrected aspect ratio thresholds to categorize the phase state of particles; these thresholds are 1.00 to $1.30,1.30$ to 1.85 , and $>1.85$ for solid, semisolid, and liquid states, respectively (Cheng et al., 2021). These thresholds were determined based on the known RH-dependent glass transition of organic material (e.g., Suwannee River fulvic acid (SRFA)) (Cheng et al., 2021). Although tilted imaging can provide a direct and convenient measurement of particle phase state, potential differences of temperature and RH inside the ESEM chamber and those at the sampling site might cause deformation of the 240 particles.

\section{Results and Discussions}

\subsection{Transport patterns and air mass sources}

In this section, we discuss the influence of varying plume ages, transport patterns, and air mass sources on the physicochemical properties of FT aerosols. We used FLEXPART retroplumes to examine transport patterns for the Pico 2017 samples up to 20 days upwind (Fig. 1) and FLEXPART CO tracer to estimate plume ages and the relative contribution of anthropogenic and wildfire emissions (Fig. S4). Transport patterns and CO source contributions for all 2014, 2015, and 2017 samples are listed in Table 1. We also analyzed the vertical distribution of air masses residence time (Fig. S5 for S3-1 to S4-4 and Fig. S6 (b, d, $\mathrm{f}, \mathrm{h}, \mathrm{j}, \mathrm{i}$ ) for S1 to S6) and the temperature and relative humidity (RH) during transport for a better understanding of ambient conditions that are critical for aerosol property transition. Figure 1(a) shows that sample S3-1 was collected during a 6-day period of recirculation over the North Atlantic Ocean. About $80 \%$ of S3-1 air masses were contributed from anthropogenic emission from North America based on CO sources contribution, and it was also expected to be influenced by ocean sea sprays 
due to its long residence time over the ocean and air mass contributions in the marine boundary layer (Fig. S5(a)). All the other samples (Fig. 1 (b to h)) were dominated by air masses from North America but differed in transport pathways, travel distances, and impact from anthropogenic and wildfire emissions. Although samples S3-2 and S3-3 were collected on the same day, the CO contributions of sources were different (Table 1). Comparing the retroplumes of S3-2 and S3-3 (Fig. 1 (b and C)), air masses of S3-2 and S3-3 were transported across the United States (contribution from anthropogenic CO sources were $\sim 47 \%$ and $\sim 31 \%$, respectively) and received air masses from Africa (contribution from anthropogenic CO sources are $\sim 17 \%$ and $\sim 16 \%$, respectively) before reaching OMP. Moreover, retroplumes also show that S3-3 received larger air masses from Central America than S3-2, and CO tracer analysis further shows those air masses were originated from South America (contribution from anthropogenic CO sources were $\sim 32 \%$ and $\sim 50 \%$, respectively). Air masses of S3-4 were transported across the United States (contribution from anthropogenic CO sources were $\sim 21 \%$ ) and then combined with outflow from Asia (contribution from anthropogenic CO sources were $\sim 63 \%$ ). Air masses of S4-1, S4-3, and S4-4 were transported across the United States and received air masses from Canada, and the transport period from North America to OMP was approximately 7, 5, and 5 days, respectively. Their North American anthropogenic CO contributions were $\sim 70 \%, \sim 22 \%$, and $\sim 48 \%$, respectively. Air masses of S4-2 were transported from the Arctic and then transported across Canada, and the transport period for the S4-2 air masses from Canada to OMP was roughly 5 days. S4-2 air mass also has been influenced by air masses from Europe and Asia (contribution of Europe and Asia anthropogenic CO sources were $\sim 3 \%$ and $61 \%$, respectively). For S4-1 to S4-4, wildfire emission also had significant CO contributions ( $21 \%, \sim 35 \%, \sim 50 \%$, and $\sim 44 \%$, respectively) (Table 1 and Fig. S4). The estimated average plume ages are listed in Table 1. As shown in Table 1, all samples have been highly aged during long-range transport and have similar aging times ( $\sim 13$ days). Sample S4-4 has the shortest aging time ( $\sim 11$ days), and the samples S4-1 and S4-2 have the longest aging time ( $\sim 14$ days).

We also performed the same FLEXPART analyses on Pico 2014 and 2015 samples (SA1 to SA3 and S1 to S6) to trace the retroplumes of air masses and sources of these air masses, and the results were listed in Table 1. FLEXPART simulation results for Pico 2014 samples have been discussed in Lata et al., 2021. Briefly, air masses for SA1 and SA2 originated in Eastern U.S. and recirculated over the North Atlantic Ocean, and air mass for SA3 originated in Canada and the U.S. and recirculated over the North Atlantic Ocean. The average atmospheric aging time for SA1, SA2, and SA3 was $\sim 16$ days. Based on the CO tracer analysis, the major $\mathrm{CO}$ sources of SA1 were anthropogenic emissions in North America ( $46 \%)$, anthropogenic emissions in South America ( $\sim 12 \%)$, and wildfire in North America ( 27\%). For SA2, the major CO sources were North America anthropogenic emissions ( $\sim 38 \%)$, Africa anthropogenic emissions ( $24 \%)$, and North America wildfire ( 29 \%). For SA3, anthropogenic ( $\sim 5 \%$ ) and wildfire ( $46 \%$ ) emissions in North America were two major CO sources (Lata et al., 2021). Like Pico 2014 and Pico 2017 samples, all Pico 2015 samples originated from North America and then recirculated over the North Atlantic Ocean (Fig. S6). Based on the CO tracer simulation (Fig. S7), the major source of CO for sample S2 was anthropogenic emissions in North America ( $84 \%$ ), and S1, S3, and S6 were influenced by both anthropogenic and wildfire CO emissions in North America $(\sim 56 \%, \sim 79 \%, \sim 40 \%$, and $\sim 59 \%$ for anthropogenic CO source, and $\sim 42 \%, \sim 19 \%, \sim 53 \%$, and $\sim 25 \%$ for 
wildfire CO sources, respectively). Wildfire emission in North America is the major CO source of S4 ( 91\%). The average aging time for Pico 2015 samples was varied between $\sim 10$ and $\sim 17$ days.

\subsection{Chemical characterization of the OMP samples}

\subsubsection{Chemical-resolved size distribution of individual particle}

290 Figure 2 shows SMPS size distribution and total particle concentration at OMP (5 July 2017 to 24 July 2017). Mobility diameter ranged from $30 \mathrm{~nm}$ to $500 \mathrm{~nm}$, and the mode was around $100 \mathrm{~nm}$. The total particle concentration was around $300 \mathrm{~cm}^{-3}$, and, in general, a higher concentration of particles ( $>400$ particles $\mathrm{cm}-3)$ was observed during high $\mathrm{CO}$ concentration periods derived from the FLEXPART simulation. The size range and particle concentration were within this range for FT particles reported in the literature (Igel et al., 2017; Rose et al., 2017; Schmeissner et al., 2011; Sun et al., 2021).

295 Figure 3 shows chemically resolved size distributions inferred from the CCSEM-EDX data. The total number of each particle class in each sample is listed in Table S2. Our particles are internally mixed based on tilted transmission electron microscopy (TEM, the titled angle was $70^{\circ}$ ) (Fig. S8). Figure 3 (a) shows the average number fraction of different particle types in each sample, and Fig. 2(b to i) show chemically-specific normalized particle size distributions. Overall, the carbonaceous aerosols $(\mathrm{OC}+\mathrm{CNO})$ have the highest number fraction in samples S3-2 to S4-4 ( 42 to 69 \%) and the second-highest in sample S4-1

300 ( $\sim 30 \%)$. Moreover, sea salt and sea salt with sulfate particles are a significant fraction in each sample ( $~ 8.8$ to $31.59 \%$, and $\sim 5.2$ to $31.5 \%$, respectively). Sea salt particles were typically from marine sprays since air masses were transported over the North Atlantic Ocean. Sea salt with sulfate particles with area equivalent diameter greater than $0.6 \mu \mathrm{m}$ have been shown to be a product of aqueous-phase processing (i.e., fog and cloud processing) (Ervens et al., 2011; Kim et al., 2019; Lee et al., 2011, 2012; Zhou et al., 2019), and those with area equivalence diameter less than $0.6 \mu \mathrm{m}$ might have been generated from marine

305 sources (Sorooshian et al., 2007; Yu et al., 2005). Sea salt and sea salt with sulfate particles dominate $(\sim 28.2 \%$ and $\sim 31.5 \%$, respectively) in sample S3-1, with a smaller fraction of organic particles (CNO and CNOS, $\sim 79.6 \%$ and $\sim 1.1 \%$, respectively) than in other samples. This result is supported by the FLEXPART retroplumes, which suggested a 6- to 7-day long recirculation over the North Atlantic Ocean, making marine spray particles have a more considerable impact. Although sample S3-2 was collected 2 hours before S3-3, their chemical compositions differed. S3-2 has more CNO and less OC and sea salt particles

310 than S3-3, which might be due to a larger contribution from Asia and a smaller contribution from South America and the Pacific Ocean than S3-3 (Table 1 and Fig. 1 (b and c)). Details of the chemically resolved size distribution for Pico 2014 samples have been discussed in Lata et al., 2021. Briefly, all samples (SA1, SA2, and SA3) are dominated by carbonaceous particles ( $\sim 68 \%, \sim 57 \%$, and $\sim 67 \%$ by number, respectively). Besides carbonaceous particles, there are high fractions of CNOS particles in SA1 and SA3 ( 14\% and $\sim 23 \%$, respectively), suggesting potential cloud processing. $\sim 11 \%$ of particles

315 in SA1 are dust, which might have originated from Africa. The fraction of sea salt particles is high in SA2 ( $23 \%)$ due to longer recirculation time over the North Arctic Ocean ( 15 days) (Lata et al., 2021). For Pico 2015 samples, carbonaceous particles dominate S1 and S3 to S6 ( $\sim 2 \%, \sim 63 \%, \sim 80 \%, \sim 52 \%$, and $\sim 61 \%$, respectively). Sulfate (CNOS and sea salt with 
sulfate) particles are also very abundant in all samples ( 18 to $34 \%)$, suggesting that these particles were involved in cloud processing (Ervens et al., 2011; Kim et al., 2019; Lee et al., 2011, 2012; Zhou et al., 2019). Sample S2 and S5 have high dust contributions ( $\sim 16 \%$ and $\sim 14 \%$, respectively) due to air masses coming from Africa. In oncoming work, we will discuss the particles' chemically resolved size distributions in more detail.

\subsubsection{Chemical imaging of individual particle}

Figure 4 shows the STXM-NEXAFS Carbon K-edge chemical speciation maps and spectra of four typical particle mixing states of OC (green), IN (blue), and EC (red) found in S3-3 and S4-2, which are (a) organic particle (green), (b) EC core (red) and coated by OC (green), (c) internally mixed EC (red) and In (cyan) coated by OC (green), and (d) In (cyan) coated by OC (green). The STXM-NEXAFS spectra for these four types of particles show that one of the major components in these particles is $\mathrm{OC}$ since the intensity of $\mathrm{R}-\mathrm{COOH}(288.5 \mathrm{eV})$ and $\mathrm{R}(\mathrm{C}=\mathrm{O}) / \mathrm{C}-\mathrm{OH}(286.5 \mathrm{eV})$ peaks are more intense. However, particles also contain inorganic components. This observation is consistent with their STXM images and tilted TEM images (Fig. S8). Moreover, STXM images indicate that particles are internally mixed and coated by organic species, suggesting our samples might be highly aged during transport in the FT (China et al., 2015; Motos et al., 2020).

The particle chemically resolved size distributions for all samples analyzed with STXM-NEXAFS are shown in Fig. S9. In S3-3 and S4-4 samples, OCIn particles are the dominating class ( $\sim 87.8 \%$ and $\sim 98.8 \%$, respectively), and there is only a very small fraction of OC ( $\sim 5.2 \%$ and $\sim 1.2 \%$, respectively). Based on the CCSEM-EDX measurements, most inorganic species are sea salt, which might have originated from the marine boundary layer while the air mass crossed the Atlantic Ocean.

335 Moreover, we did not find any EC, In, and OCEC in either sample, but we found a small portion of OCInEC ( $7.0 \%)$ in S33. For Pico 2014 samples, OCIn particles are also dominant ( $\sim 3 \%, \sim 64 \%$, and $\sim 77 \%$ for SA1, SA2, and SA3, respectively) (Lata et al., 2021). For SA1 and SA3, these inorganic species might come from sulfate generated from cloud processing, and for SA2, these inorganics might come from sea sprays (Lata et al., 2021). For Pico 2015 samples, S3 is dominated by OC ( 69 $\%)$. S5 also has a significant fraction of OC ( $22 \%)$, but OCIn and OCInEC are more dominating $(\sim 35 \%$ and $\sim 38 \%$,

340 respectively). The EC might originate from wildfire (see Sect. 3.1), and inorganics might come from sea spray and cloud processing (see Sect. 3.2.1).

\subsection{Phase state of particles}

\subsubsection{Phase state of particles at the OMP site}

As discussed in Sect. 2.4, we used tilted view SEM images to determine the particles' phase state at OPM. Figure 5 shows

345 violin plots of the 'corrected' aspect ratio (left) and representative tilted images (right) for Pico 2014 (a to c), Pico 2015 (d to i), and Pico 2017 (j to q). The number fraction of particles in each phase state for Pico 2014, 2015, and 2017 samples are listed in Table 1. As shown in Fig. 5, all samples are dominated by liquid particles (ranges from $\sim 47 \%$ to $\sim 99 \%$ by number) at the time of sample collection during summertime. We also observed considerable fractions of semisolid ( 1 to $42 \%)$ and solid 
particles ( $\sim 0$ to $30 \%$ ) for specific events, suggesting that the abundance of liquid, semisolid and solid particles in FT depend on atmospheric transport events and particle sources. A potential explanation of the high fraction of liquid particles is that our samples are internally mixed with inorganic species based on the tilted TEM images, CCSEM-EDX, and STXM-NEXAFS measurements (see Sect. 3.2). Previous laboratory studies have found that the viscosity of a homogeneous internally mixed particle of organics and inorganics (e.g., nitrate, sulfate, and sodium salt) decreases with increasing fraction of inorganic (Dette and Koop, 2015; Power et al., 2013; Rovelli et al., 2019; Saukko et al., 2012; Schill and Tolbert, 2014; Song et al., 2021; Wang

355 et al., 2015) since these inorganics are more hygroscopic and increasing the overall hygroscopicity of internally mixed particles. Moreover, limited field studies have investigated the influence of inorganic inclusions on the viscosity and/or phase state of ambient organic aerosols and found similar results as laboratory studies (Liu et al., 2019; Slade et al., 2019). Slade et al., 2019 performed field measurements at the University of Houston Mobile Air Quality Laboratory (UHMAQL) and found that aerosols are less viscous and more liquid state aerosols during daytime than night due to higher amounts of inorganic sulfate. Liu et al., 2019 have found that particles in Shenzhen, China, from 17 April to 11 May 2017, were abundant in the liquid state $(43 \pm 6 \%)$ due to high inorganic mass fraction in particles $(62.6 \pm 12.4 \%$ of dry particles, on average). Thus, these laboratory and field studies support our findings since our samples have abundant inorganic species inclusions such as sea salt and sulfate (see Sect. 3.2), and the elemental percentage of elements associated with these species ( $\mathrm{Na}, \mathrm{Mg}, \mathrm{Al}, \mathrm{P}, \mathrm{S}$, and $\mathrm{K}$ ) are ranged from $\sim 1.2 \%$ to $15.9 \%$ (see Table 1 ). Besides the inorganic species internally mixed with organic species, another potential explanation of the abundance of liquid particles in our samples might be that our samples were highly aged during long-range transport since their average aging times were more than 10 days. Aging processes can reduce the particles' viscosity due to photodegradation and photobleaching (Koop et al., 2011; Malecha and Nizkorodov, 2016; Pajunoja et al., 2016; Pan et al., 2009; Sumlin et al., 2017). The substantial fraction of solid and semisolid particles might be less oxidized. A previous study at Pico investigated the molecular composition of water-soluble organic matter and found compounds with low oxygenation (Dzepina et al., 2015). The authors hypothesized that aqueous-phase processing (cloud processing) and fragmentation (photolysis) might be responsible for the selective removal of some fraction of highly aged polar compounds. Similarly, another study at the site highlighted organic components (after removing the inorganic salts) with lower $\mathrm{O} / \mathrm{C}$ ratio, and particles were in the solid state during the long-range transport (Schum et al., 2018). These results suggest that apart from environmental factors, the inorganic components, the molecular weight of organic compounds, and the $\mathrm{O} / \mathrm{C}$ ratio (or aging time) all affect the phase state of internally mixed particles.

Moreover, we observed two different types of aspect ratio distributions: (a) narrow distribution with mean aspect ratios below 4 and a larger fraction of particles with aspect ratios greater than 4 (<35\%) (standard deviation ranges from 0.9 to 2.1$)$ (Fig. $5(\mathrm{a}, \mathrm{d}, \mathrm{e}, \mathrm{I}$, and $\mathrm{j}$ to $\mathrm{o})$ ), and (b) broad distribution with a larger fraction of particles with aspect ratios greater than $4(>40 \%)$

380 (standard deviation ranges from 1.4 to 2.4) (Fig. 5(b, c, f, g, h, p, and q)). The correlation analyses of aspect ratio against the FLEXPART CO tracer suggest that sources of samples that have the type (b) distribution usually have a high CO contribution from wildfires (>30 \%). There are two exceptions, S4-2 from Pico 2017 and S1 from Pico 2015, which received wildfire CO 
contributions greater than $30 \%(\sim 35 \%$ and $\sim 42 \%$, respectively) but have type (a) distribution shape. For S4-2, a possible reason is that the volatile and less viscous species of particles collected on the TEM grid have already evaporated and left these tiny residuals around those big particles (see Fig. 5(f) right panel) due to difference in temperature, RH, and pressure between OMP and SEM chamber. Hence, those particles remaining on the substrate have a higher viscosity than the original particles. For S1, the altitude of the center of air mass during transport was lower than other samples (Fig. S6 (b)), which might make S1 have more considerable impacts from PBL. To test the hypothesis that source and FT aerosols' viscosity are correlated, we applied a paired-difference t-test $(\alpha=0.05)$ of the number fraction of particles that have aspect ratios greater than 4 (see Table 1) and the contribution of wildfires $\mathrm{CO}$ source based on the FLEXPART CO tracer simulation (see Table 1), and the results suggest that these two are positively correlated $(\mathrm{p}=0.0186)$. It should be noticed that we only have a limited number of samples (17 samples) in this study. Thus, it is necessary to perform more studies to improve our knowledge of the influence of sources on FT particles' phase state and viscosity. Moreover, we also observed a considerable fraction of semisolid and solid particles in samples with high wildfire CO contribution ( $\sim$ to $29 \%$ and $\sim 0$ to $16 \%$, respectively), suggesting wildfire-influenced

395 plumes can also emit high viscous particles. The presence of high viscosity organic particles in wildfire-influenced plume in FT after long-range transport is in accordance with a previous study at Pico (Schum et al., 2018). Therefore, our results suggest that the viscosity of FT particles depends on their source, and wildfire-influenced plume results in particles with a wide range of viscosities in the FT. To date, the knowledge on the phase state and/or viscosity of wildfire aerosols is limited. Many studies have reported observations of tar balls, a solid spherical organic aerosol, in biomass emissions (Adachi et al., 2019; Adachi

400 and Buseck, 2011; China et al., 2013; Hoffer et al., 2017; Posfai et al., 2004). DeRieux et al., 2018 predicted the viscosity of biomass burning particles using their chemical composition, and they found that the viscosity of biomass burning particles varied between $10^{-2} \mathrm{~Pa} \mathrm{~S}$ and $10^{12} \mathrm{~Pa} \mathrm{~S}$ depending on the RH. Liu et al., 2021 found that ambient and lab-generated biomass burning particles are in a non-solid state at RH between $20 \%$ and $50 \%$. Therefore, these studies support our finding that biomass burning can emit particles with a broad viscosity distribution. This finding underlines the importance of constraining source-specific contributions to determine the phase state of FT particles, which is still not well documented.

Besides tilted imaging, we also investigated the phase state of particles utilizing STXM-NEXAFS measurements to retrieve the total carbon absorbance (TCA). TCA, which is proportional to the thickness of the organics (O'Brien et al., 2014), has been suggested as an indicator of particle viscosity and phase state. Typically, particles with the same area equivalent diameter 410 but higher TCA are more viscous (more solid-like) since they are less flat in shape (Fraund et al., 2020; Tomlin et al., 2020). However, if a particle has a solid inorganic core (e.g., dust or soot) and organic coating, its TCA will be low, indicating a low thickness. In this case, it is difficult to probe the phase state of the organic coating; for these cases, tilted imaging provides better estimates since we can directly observe the thickness of entire particle. Figure 6 shows the TCA as a function of the area equivalent diameter of the impacted particles for samples from Pico 2014, Pico 2015, and Pico 2017 (left panel) and a 415 histogram plot of OVF to investigate the contribution of inorganic inclusions in phase state of particles. Symbols are colored by their OVF. Shaded areas represent regions of different phase states (liquid: blue, semisolid: green, and solid: red), with the 
boundaries of each region based on (O’Brien et al., 2014). As shown in Fig. 6, TCA values for our samples are very low, and more than $90 \%$ of the particles in each sample are in the liquid state, consistent with our tilted imaging measurements. Except for S3, all samples have OVF around $0.20 \pm 0.22$, suggesting these carbonaceous particles contain other elements.

\section{$420 \quad$ 3.3.2 Phase state of particles during long-range transport}

Due to changing atmospheric conditions, the phase state of aerosols during transport might be more variable than that at the sampling site. To investigate the phase state of particles during transport, we estimated the expected phase state of the samples indirectly by calculating their glass transition temperature $\left(T_{\mathrm{g}}\right)$, which is the transition temperature between solid and semisolid states (Koop et al., 2011). To calculate $T_{\mathrm{g}}$ of a mixture (e.g., internally mixed organics and inorganics), we need to know the

425 properties of each component (e.g., mass fractions, density, hygroscopicity, and dry $T_{\mathrm{g}}$ ). Due to limited information of inorganic species' type and volume fraction in our samples, we can only predict RH-dependent $T_{\mathrm{g}}$ values of organic particles ( $T_{\mathrm{g}, \text { org }}$ ) (Koop et al., 2011). Typically, organic particles maintain solid states when $T_{\mathrm{g}, \text { org }} / T \geq 1$, semisolid state when $1>T_{\mathrm{g}, \text { org }}$ $/ T \geq 0.8$, and liquid state when $T_{\mathrm{g}, \text { org }} / T<0.8$ (Schmedding et al., 2020; Shiraiwa et al., 2017). We calculated expected $T_{\mathrm{g}, \text { org }}$ during the air mass transport using the temperature and RH extracted from the Global Forecast System (GFS) along the

430 FLEXPART simulated path. We used the density $\left(\rho_{\text {org }}\right)$, hygroscopicity $\left(\kappa_{\text {org }}\right)$, and dry glass transition temperature $\left(T_{\mathrm{g}, \text { org }, 0}\right)$ of organic particles as reported by Schum et al., 2018 (see SI) since we do not have molecular compositions for our samples and Schum et al., 2018's samples were also collected at OMP during the same seasonal period (June and July).

Predicted $T_{\mathrm{g}, \text { org }}$ based on FLEXPART for each Pico 2017 sample during transport are shown in Fig. S10. The extracted ambient temperature for all samples was relatively stable during transport and slightly increased when the air masses approached OMP. On the other hand, ambient RH was more variable from grid cell to cell. The RH decreased when the air masse reached OMP. Therefore, ambient RH and dry $T_{\mathrm{g}}$ (see SI) yield a wide range of $T_{\mathrm{g}, \text { org }}$ values $(191.1 \mathrm{~K}-329.1 \mathrm{~K})$ during transport (Fig. S10). Overall, the predicted average $T_{\mathrm{g}, \mathrm{rg}}$ values in all samples exceed the ambient temperature extracted from FLEXPART during most of the transport periods (Fig. S10), implying that organic particles would likely be solid in the FT. These results are consistent with a previous study at the site (Schum et al., 2018) and other modelling studies (Shiraiwa et al., 2017; Shrivastava et al., 2017) that organic particles in the FT are likely in solid and semisolid states. We also calculated $T_{\mathrm{g}, \text { org }}$ of organic particles at OMP using meteorological data collected at OMP (Table S2), and it also shows that the organics in our samples should have been in solid state at the time they were sampled at OMP since the predicted $T_{\mathrm{g}, \text { org }}$ is higher than the measured temperature. Moreover, $T_{\mathrm{g} \text {,org }}$ at OMP calculated using FLEXPART data is close to that calculated using the local meteorological data (difference $<4.4 \%$ ), and the difference between FLEXPART simulated temperature and RH at the site and those measured at OMP is not significant (less than $4{ }^{\circ} \mathrm{C}$ and $\mathrm{RH}$ varies between $\sim 3.5 \%$ to $\sim 12 \%$ ), which indicate that the FLEXPART data can be used to predict the phase state of organic particles during long-range transport. 
In addition to the potential difference of molecular formula of organics and ambient conditions between our study and Schum et al., 2018, our offline phase state measurements show that the samples collected at OMP might have lower $T_{\mathrm{g}}$ than the theoretically predicted $T_{\mathrm{g}, \text { org }}$. This might be due to the fact that our sampled particles were internally mixed with inorganic species (see Sect. 3.2), which are expected to decrease the viscosity and the $T_{\mathrm{g}}$ of the particles (Dette and Koop, 2015; Power et al., 2013; Rovelli et al., 2019; Saukko et al., 2012; Schill and Tolbert, 2014; Song et al., 2021; Wang et al., 2015). Moreover, in the calculation of $T_{\mathrm{g}, \text { org }}$, we assumed the CCN-derived hygroscopicity parameter of organic particles $\left(\kappa_{\text {org }}\right)$ to be 0.12 (Schum

455 et al., 2018), which might be lower than that of ambient internally mixed particles (Ching et al., 2019; Kristensen et al., 2016; Pringle et al., 2010; Schulze et al., 2020). The underestimation of $\kappa$ would lead to an overestimation of $T_{\mathrm{g}}$. Thus, our results suggest that estimating the phase state of particles without considering the mixing state of FT particles might not accurately predict their viscosity and $T_{\mathrm{g}}$. Moreover, our results highlight the essential roles of FT sites such as OMP for studying the phase state and viscosity of FT particles since these sites provide unique opportunities for comprehensively understanding FT aerosols' chemical composition, physical properties, and hygroscopicity. This information is necessary to predict the particles' phase state in the FT more accurately, which is critical for predicting their effects on climate.

\section{Conclusions}

The phase state and viscosity of free tropospheric particles are important properties for estimating the climatic effects of aerosols. However, the current understanding of phase state and viscosity is limited, especially for aerosol in the remote free

465 troposphere. In this study, we analyzed the chemical properties and phase state of single particles collected in the free troposphere at the Observatory of Mount Pico (OMP), in the Azores, over three different years. We combined the singleparticle analysis with FLEXPART analysis to estimate the particles' phase state during transport. We utilized multi-modal micro-spectroscopy techniques (CCSEM-EDX, tilted view imaging combined ESEM, and STXM-NEXAFS) to probe the chemical composition, phase state, and mixing state of long-range transported free-tropospheric particles. The source and air mass transport trajectories and ages were also determined using FLEXPART. FLEXPART CO tracer simulations showed that North American wildfire emissions primarily influenced SA3, S1, S3, S6, S4-2, S4-3, and S4-4, while the rest of the samples were largely influenced by anthropogenic sources. CCSEM-EDX analysis indicates that carbonaceous aerosols are the dominant type in all samples. Carbonaceous sulfate and sea salt with sulfate particles are also present, probably due to the contribution of marine sprays and cloud processing. The CCSEM-EDX analysis and FLEXPART simulations revealed that transport patterns could affect particle chemical composition. The offline single particle phase state analysis showed that the major fraction of particles was liquid ( $\sim 77$ to $99 \%$ ). However, there were also a considerable fraction of solid ( $\sim 0$ to $30 \%$ by number) and semisolid ( $\sim 0.1$ to $42 \%$ ) particles, and their relative abundance depends on the transport pattern and particle sources. We hypothesize that the high abundance of liquid particles is due to the presence of inorganic inclusions (e.g., sulfate and $\mathrm{Na}$ salt) and the long atmospheric aging times ( $>10$ days), which can reduce the viscosity of organics due to photodegradation and photobleaching. Moreover, we found that samples with a significant influence of wildfire emissions 
(wildfire CO contribution $>30 \%$ ) have a broad viscosity distribution than those collected during events dominated by anthropogenic emissions. This finding underscores the need to study further the influence of emission sources on the viscosity of FT particles. Our results suggest that neglecting the contribution of internally mixed inorganic species while calculating the particle hygroscopicity properties of organic aerosols might overestimate the viscosities of internally mixed particles. Indeed, the inorganic inclusions reduced the calculated particles' viscosity, implying that the particle's probability of remaining liquid in the FT is enhanced. These effects have been previously shown in laboratory studies by measuring the viscosity of organic and inorganic mixtures (Dette and Koop, 2015; Power et al., 2013; Rovelli et al., 2019; Saukko et al., 2012; Schill and Tolbert, 2014; Song et al., 2021; Wang et al., 2015) and in ambient samples (Liu et al., 2019; Slade et al., 2019). Moreover, the effects of internally mixed inorganics on the particle's viscosity are not considered in current climate models (Rasool et al., 2021; Schmedding et al., 2020; Shiraiwa et al., 2017). These liquid particles are expected to be less stable and have faster heterogeneous reaction rates, be more reactive, and be quickly photodegraded in the FT (Berkemeier et al., 2016; Kuwata and Martin, 2012; Lienhard et al., 2015; Liu et al., 2018a; Marshall et al., 2016; Pöschl and Shiraiwa, 2015b; Renbaum-Wolff et al., 2013). This study demonstrates the phase state of internally mixed particles in the FT and highlights the importance of accounting for the inorganic inclusions to evaluate the phase state of internally mixed particles.

Supplement. The supplement related to this article is available online at:

Author Contribution. ZC, CM, and SC designed the study. BW, SH, LM, and CM collected samples and performed online measurements. ZC, MM, NNL, RB, and SC performed microscopy experiments and analysis; ZC, NNL, MAM, and SC 500 performed STXM/NEXAFS experiments and analysis. BZ performed FLEXPART simulation. ZC wrote the first manuscript draft. All authors reviewed and edited the manuscript.

Data Availability. All the measurement data are provided in the supplement

505 Competing Interests. The authors declare that they have no conflict of interest.

Acknowledgments. A portion of this research was performed on a project award (10.46936/1ser.proj.2019.50835/60000118) from the Environmental Molecular Sciences Laboratory, a DOE Office of Science User Facility sponsored by the Biological and Environmental Research program under Contract No. DE-AC05-76RL01830. STXM/NEXAFS analysis at beamline 510 5.3.2.2 of the Advanced Light Source at Lawrence Berkeley National Laboratory is supported by the Director, Office of Science, Office of Basic Energy Sciences of the U.S. Department of Energy under Contract No. DE-AC02- 05CH11231. We acknowledge funding from the U.S. Department of Energy, Office of Science (BER), Atmospheric System Research. The sample collection at Pico Mountain Observatory was supported with funding from NSF (AGS-1110059), DOE (DESC0006941), and NASA's Earth and Space Science Graduate Fellowships (NNX12AN97H, and NNX13AN68H). Logistic 
https://doi.org/10.5194/acp-2022-84

Preprint. Discussion started: 11 February 2022

(c) Author(s) 2022. CC BY 4.0 License.

(c) (1)

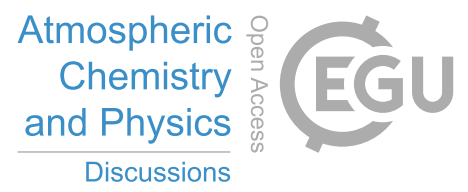

515 support for the Observatory's operation was provided by the Regional Government of the Azores through the Regional Secretary for Science and the Pico Island Natural Park. We thank Mike Dziobak, Kendra Wright, Sumit Kumar, Andrea Baccarini, Stefano Viviani, Jacques Huber, and Detlev Helmig for support in the field. Measurements in 2017 were funded by the German Science Foundation (Deutsche Forschungsgemeinschaft, DFG) under SI 1543/4-1, WE 2757/2-1, and HE 6770/21. 


\section{Reference:}

Adachi, K. and Buseck, P. R.: Atmospheric tar balls from biomass burning in Mexico, J. Geophys. Res., 116(5), 2-8, doi:10.1029/2010JD015102, 2011.

Adachi, K., Sedlacek, A. J., Kleinman, L., Springston, S. R., Wang, J., Chand, D., Hubbe, J. M., Shilling, J. E., Onasch, T. B., Kinase, T., Sakata, K., Takahashi, Y. and Buseck, P. R.: Spherical tarball particles form through rapid chemical and physical changes of organic matter in biomass-burning smoke, Proc. Natl. Acad. Sci. U. S. A., 116(39), 19336-19341, doi:10.1073/pnas.1900129116, 2019.

530 Bateman, A. P., Belassein, H. and Martin, S. T.: Impactor apparatus for the study of particle rebound: Relative humidity and capillary forces, Aerosol Sci. Technol., 48(1), 42-52, doi:10.1080/02786826.2013.853866, 2014.

Bateman, A. P., Bertram, A. K. and Martin, S. T.: Hygroscopic Influence on the Semisolid-to-Liquid Transition of Secondary Organic Materials, J. Phys. Chem., 119(19), 4386-4395, doi:10.1021/jp508521c, 2015.

Bateman, A. P., Gong, Z., Liu, P., Sato, B., Cirino, G., Zhang, Y., Artaxo, P., Bertram, A. K., Manzi, A. O., Rizzo, L. V.,

535 Souza, R. A. F., Zaveri, R. A. and Martin, S. T.: Sub-micrometre particulate matter is primarily in liquid form over Amazon rainforest, Nat. Geosci., 9(1), 34-37, doi:10.1038/ngeo2599, 2016.

Bateman, A. P., Gong, Z., Harder, T. H., De Sá, S. S., Wang, B., Castillo, P., China, S., Liu, Y., O’Brien, R. E., Palm, B. B., Shiu, H. W., Cirino, G. G., Thalman, R., Adachi, K., Lizabeth Alexander, M., Artaxo, P., Bertram, A. K., Buseck, P. R., Gilles, M. K., Jimenez, J. L., Laskin, A., Manzi, A. O., Sedlacek, A., Souza, R. A. F., Wang, J., Zaveri, R. and Martin, S. T.:

540 Anthropogenic influences on the physical state of submicron particulate matter over a tropical forest, Atmos. Chem. Phys., 17(3), 1759-1773, doi:10.5194/acp-17-1759-2017, 2017.

Bellouin, N., Quaas, J., Gryspeerdt, E., Kinne, S., Stier, P., Watson-Parris, D., Boucher, O., Carslaw, K. S., Christensen, M., Daniau, A. L., Dufresne, J. L., Feingold, G., Fiedler, S., Forster, P., Gettelman, A., Haywood, J. M., Lohmann, U., Malavelle, F., Mauritsen, T., McCoy, D. T., Myhre, G., Mülmenstädt, J., Neubauer, D., Possner, A., Rugenstein, M., Sato, Y., Schulz,

545 M., Schwartz, S. E., Sourdeval, O., Storelvmo, T., Toll, V., Winker, D. and Stevens, B.: Bounding Global Aerosol Radiative Forcing of Climate Change, Rev. Geophys., 58(1), 1-45, doi:10.1029/2019RG000660, 2020.

Berkemeier, T., Shiraiwa, M., Pöschl, U. and Koop, T.: Competition between water uptake and ice nucleation by glassy organic aerosol particles, Atmos. Chem. Phys., 14(22), 12513-12531, doi:10.5194/acp-14-12513-2014, 2014.

Berkemeier, T., Steimer, S. S., Krieger, U. K., Peter, T., Pöschl, U., Ammann, M. and Shiraiwa, M.: Ozone uptake on glassy,

550 semi-solid and liquid organic matter and the role of reactive oxygen intermediates in atmospheric aerosol chemistry, PCCP, 18(18), 12662-12674, doi:10.1039/c6cp00634e, 2016.

Bianchi, F., Tröstl, J., Junninen, H., Frege, C., Henne, S., Hoyle, C. R., Molteni, U., Herrmann, E., Adamov, A., Bukowiecki, N., Chen, X., Duplissy, J., Gysel, M., Hutterli, M., Kangasluoma, J., Kontkanen, J., Kürten, A., Manninen, H. E., Münch, S., Peräkylä, O., Petäjä, T., Rondo, L., Williamson, C., Weingartner, E., Curtius, J., Worsnop, D. R., Kulmala, M., Dommen, J. and Baltensperger, U.: New particle formation in the free troposphere: A question of chemistry and timing, Science (80-. )., 
352(6289), 1109-1112, doi:10.1126/science.aad5456, 2016.

Bond, T. C., Doherty, S. J., Fahey, D. W., Forster, P. M., Berntsen, T., Deangelo, B. J., Flanner, M. G., Ghan, S., Kärcher, B., Koch, D., Kinne, S., Kondo, Y., Quinn, P. K., Sarofim, M. C., Schultz, M. G., Schulz, M., Venkataraman, C., Zhang, H., Zhang, S., Bellouin, N., Guttikunda, S. K., Hopke, P. K., Jacobson, M. Z., Kaiser, J. W., Klimont, Z., Lohmann, U., Schwarz,

560 J. P., Shindell, D., Storelvmo, T., Warren, S. G. and Zender, C. S.: Bounding the role of black carbon in the climate system: A scientific assessment, Geophys. Res. Atmos., 118(11), 5380-5552, doi:10.1002/jgrd.50171, 2013.

Bondy, A. L., Bonanno, D., Moffet, R. C., Wang, B., Laskin, A. and Ault, A. P.: The diverse chemical mixing state of aerosol particles in the southeastern United States, Atmos. Chem. Phys., 18(16), 12595-12612, doi:10.5194/acp-18-12595-2018, 2018. Boose, Y., Kanji, Z. A., Kohn, M., Sierau, B., Zipori, A., Crawford, I., Lloyd, G., Bukowiecki, N., Herrmann, E., Kupiszewski,

565 P., Steinbacher, M. and Lohmann, U.: Ice nucleating particle measurements at $241 \mathrm{~K}$ during winter months at 3580m MSL in the swiss alps, J. Atmos. Sci., 73(5), 2203-2228, doi:10.1175/JAS-D-15-0236.1, 2016.

Briggs, N. L., Jaffe, D. A., Gao, H., Hee, J. R., Baylon, P. M., Zhang, Q., Zhou, S., Collier, S. C., Sampson, P. D. and Cary, R. A.: Particulate matter, ozone, and nitrogen species in aged wildfire plumes observed at the Mount Bachelor Observatory, Aerosol Air Qual. Res., 16(12), 3075-3087, doi:10.4209/aaqr.2016.03.0120, 2016.

570 Cheng, Z., Sharma, N., Tseng, K.-P., Kovarik, L. and China, S.: Direct observation and assessment of phase states of ambient and lab-generated sub-micron particles upon humidification, RSC Adv., 11, 15264-15272, doi:10.1039/d1ra02530a, 2021.

China, S., Mazzoleni, C., Gorkowski, K., Aiken, A. C. and Dubey, M. K.: Morphology and mixing state of individual freshly emitted wildfire carbonaceous particles, Nat. Commun., 4, 2122, doi:10.1038/ncomms3122, 2013.

China, S., Scarnato, B., Owen, R. C., Zhang, B., Ampadu, M. T., Kumar, S., Dzepina, K., Dziobak, M. P., Fialho, P., Perlinger,

575 J. A., Hueber, J., Helmig, D., Mazzoleni, L. R. and Mazzoleni, C.: Morphology and mixing state of aged soot particles at a remote marine free troposphere site: Implications for optical properties, Geophys. Res. Lett., 42(4), 1243-1250, doi:10.1002/2014GL062404, 2015.

China, S., Alpert, P. A., Zhang, B., Schum, S., Dzepina, K., Wright, K., Owen, R. C., Fialho, P., Mazzoleni, L. R., Mazzoleni, C. and Knopf, D. A.: Ice cloud formation potential by free tropospheric particles from long-range transport over the Northern

580 Atlantic Ocean, J. Geophys. Res. Atmos., 122(5), 3065-3079, doi:10.1002/2016JD025817, 2017.

Ching, J., Fast, J., West, M. and Riemer, N.: Metrics to quantify the importance of mixing state for CCN activity, Atmos. Chem. Phys., 17(12), 7445-7458, doi:10.5194/acp-17-7445-2017, 2017.

Ching, J., Adachi, K., Zaizen, Y., Igarashi, Y. and Kajino, M.: Aerosol mixing state revealed by transmission electron microscopy pertaining to cloud formation and human airway deposition, npj Clim. Atmos. Sci., 2(1), 1-7, doi:10.1038/s41612585 019-0081-9, 2019.

Clarke, A. D., Freitag, S., Simpson, R. M. C., Hudson, J. G., Howell, S. G., Brekhovskikh, V. L., Campos, T., Kapustin, V. N. and Zhou, J.: Free troposphere as a major source of $\mathrm{CCN}$ for the equatorial pacific boundary layer: Long-range transport and teleconnections, Atmos. Chem. Phys., 13(15), 7511-7529, doi:10.5194/acp-13-7511-2013, 2013.

Coen, M. C., Andrews, E., Aliaga, D., Andrade, M., Angelov, H., Bukowiecki, N., Ealo, M., Fialho, P., Flentje, H., Gannet 
590 Hallar, A., Hooda, R., Kalapov, I., Krejci, R., Lin, N. H., Marinoni, A., Ming, J., Nguyen, N. A., Pandolfi, M., Pont, V., Ries, L., Rodríguez, S., Schauer, G., Sellegri, K., Sharma, S., Sun, J., Tunved, P., Velasquez, P. and Ruffieux, D.: Identification of topographic features influencing aerosol observations at high altitude stations, Atmos. Chem. Phys., 18(16), 12289-12313, doi:10.5194/acp-18-12289-2018, 2018.

Cozic, J., Verheggen, B., Wiangartner, E., Crosier, J., Bower, K. N., Flynn, M., Coe, H., Henning, S., Steinbacher, M., Henne,

595 S., Collaud Coen, M., Petzold, A. and Baltensperger, U.: Chemical composition of free tropospheric aerosol for PM1 and coarse mode at the high alpine site Jungfraujoch, Atmos. Chem. Phys., 8(2), 407-423, doi:10.5194/acp-8-407-2008, 2008.

DeRieux, W. S. W., Li, Y., Lin, P., Laskin, J., Laskin, A., Bertram, A. K., Nizkorodov, S. A. and Shiraiwa, M.: Predicting the glass transition temperature and viscosity of secondary organic material using molecular composition, Atmos. Chem. Phys., 18(9), 6331-6351, doi:10.5194/acp-18-6331-2018, 2018.

600 Dette, H. P. and Koop, T.: Glass Formation Processes in Mixed Inorganic / Organic Aerosol Particles, J. Phys. Chem. A, 119, 4552-4561, doi:10.1021/jp5106967, 2015.

Dunlea, E. J., Decarlo, P. F., Aiken, A. C., Kimmel, J. R., Peltier, R. E., Weber, R. J., Tomlinson, J., Collins, D. R., Shinozuka, Y., McNaughton, C. S., Howell, S. G., Clarke, A. D., Emmons, L. K., Apel, E. C., Pflster, G. G., Van Donkelaar, A., Martin, R. V., Millet, D. B., Heald, C. L. and Jimenez, J. L.: Evolution of Asian aerosols during transpacific transport in INTEX-B,

605 Atmos. Chem. Phys., 9(19), 7257-7287, doi:10.5194/acp-9-7257-2009, 2009.

Dzepina, K., Mazzoleni, C., Fialho, P., China, S., Zhang, B., Owen, R. C., Helmig, D., Hueber, J., Kumar, S., Perlinger, J. A., Kramer, L. J., Dziobak, M. P., Ampadu, M. T., Olsen, S., Wuebbles, D. J. and Mazzoleni, L. R.: Molecular characterization of free tropospheric aerosol collected at the Pico Mountain Observatory: A case study with a long-range transported biomass burning plume, Atmos. Chem. Phys., 15(9), 5047-5068, doi:10.5194/acp-15-5047-2015, 2015.

610 Ervens, B., Turpin, B. J. and Weber, R. J.: Secondary organic aerosol formation in cloud droplets and aqueous particles (aqSOA): A review of laboratory, field and model studies, Atmos. Chem. Phys, 11(21), 11069-11102, doi:10.5194/acp-1111069-2011, 2011.

Fan, J., Wang, Y., Rosenfeld, D. and Liu, X.: Review of aerosol-cloud interactions: Mechanisms, significance, and challenges, J. Atmos. Sci., 73(11), 4221-4252, doi:10.1175/JAS-D-16-0037.1, 2016.

615 Fischer, H., Kormann, R., Klüpfel, T., Gurk, C., Königstedt, R., Parchatka, U., Mühle, J., Rhee, T. S., Brenninkmeijer, C. A. M., Bonasoni, P. and Stohl, A.: Ozone production and trace gas correlations during the June 2000 MINATROC intensive measurement campaign at Mt. Cimone, Atmos. Chem. Phys., 3(3), 725-738, doi:10.5194/acp-3-725-2003, 2003.

Fraund, M., Park, T., Yao, L., Bonanno, D., Pham, D. Q. and Moffet, R. C.: Quantitative capabilities of STXM to measure spatially resolved organic volume fractions of mixed organic/inorganic particles, Atmos. Meas. Tech., 12(3), 1619-1633, doi:10.5194/amt-2018-351, 2019.

Fraund, M., Bonanno, D., China, S., Pham, D., Veghte, D., Weis, J., Kulkarni, G., Teske, K., Gilles, M., Laskin, A. and Moffet, R.: Optical properties and composition of viscous organic particles found in the Southern Great Plains, Atmos. Chem. Phys., 20, 11593-11606, doi:10.5194/acp-2020-255, 2020. 

western trans-Himalayas, Atmos. Environ., 84, 262-274, doi:10.1016/j.atmosenv.2013.11.029, 2014.

Haywood, J. and Boucher, O.: Estimates of the direct and indirect radiative forcing due to tropospheric aerosols: A review, Rev. Geophys., 38(4), 513-543, doi:10.1029/1999RG000078, 2000.

Hodas, N., Zuend, A., Mui, W., Flagan, R. C. and Seinfeld, J. H.: Influence of particle-phase state on the hygroscopic behavior

630 of mixed organic-inorganic aerosols, Atmos. Chem. Phys., 15(9), 5027-5045, doi:10.5194/acp-15-5027-2015, 2015.

Hoffer, A., Tóth, Á., Pósfai, M., Chung, C. E. and Gelencsér, A.: Brown carbon absorption in the red and near-infrared spectral region, Atmos. Meas. Tech., 10(6), 2353-2359, doi:10.5194/amt-10-2353-2017, 2017.

Honrath, R. E., Owen, R. C., Val Martín, M., Reid, J. S., Lapina, K., Fialho, P., Dziobak, M. P., Kleissl, J. and Westphal, D. L.: Regional and hemispheric impacts of anthropogenic and biomass burning emissions on summertime $\mathrm{CO}$ and $\mathrm{O} 3$ in the

635 North Atlantic lower free troposphere, J. Geophys. Res., 109(24), 1-17, doi:10.1029/2004JD005147, 2004.

Hosny, N. A., Fitzgerald, C., Vyšniauskas, A., Athanasiadis, A., Berkemeier, T., Uygur, N., Pöschl, U., Shiraiwa, M., Kalberer, M., Pope, F. D. and Kuimova, M. K.: Direct imaging of changes in aerosol particle viscosity upon hydration and chemical aging, Chemi, 7(2), 1357-1367, doi:10.1039/c5sc02959g, 2016.

Huang, J., Minnis, P., Chen, B., Huang, Z., Liu, Z., Zhao, Q., Yi, Y. and Ayers, J. K.: Long-range transport and vertical

640 structure of Asian dust from CALIPSO and surface measurements during PACDEX, J. Geophys. Res. Atmos, 113(23), 1-13, doi:10.1029/2008JD010620, 2008.

Igel, A. L., Ekman, A. M. L., Leck, C., Tjernström, M., Savre, J. and Sedlar, J.: The free troposphere as a potential source of arctic boundary layer aerosol particles, Geophys. Res. Lett., 44(13), 7053-7060, doi:10.1002/2017GL073808, 2017.

Ilotoviz, E., Ghate, V. P. and Raveh-Rubin, S.: The Impact of Slantwise Descending Dry Intrusions on the Marine Boundary

645 Layer and Air-Sea Interface Over the ARM Eastern North Atlantic Site, J. Geophys. Res. Atmos., 126(4), e2020JD033879, doi:10.1029/2020JD033879, 2021.

IPCC: Climate Change 2013: The Physical Science Basis. Contribution of Working Group I to the Fifth Assessment Report of the Intergovernmental Panel on Climate Change, Chapter 8: Anthropogenic and Natural Radiative Forcing, edited by V. B. and P. M. M. (eds. . Stocker, T.F., D. Qin, G.-K. Plattner, M. Tignor, S.K. Allen, J. Boschung, A. Nauels, Y. Xia, Cambridge, United Kingdom and New York, NY, USA., 2013.

Jaffe, D., Prestbo, E., Swartzendruber, P., Weiss-Penzias, P., Kato, S., Takami, A., Hatakeyama, S. and Kajii, Y.: Export of atmospheric mercury from Asia, Atmos. Environ., 39(17), 3029-3038, doi:10.1016/j.atmosenv.2005.01.030, 2005.

Jain, S. and Petrucci, G. A.: A new method to measure aerosol particle bounce using a cascade electrical low pressure impactor, Aerosol Sci. Technol., 49(6), 390-399, doi:10.1080/02786826.2015.1036393, 2015.

655 Kaiser, J. W., Heil, A., Andreae, M. O., Benedetti, A., Chubarova, N., Jones, L., Morcrette, J. J., Razinger, M., Schultz, M. G., Suttie, M. and Van Der Werf, G. R.: Biomass burning emissions estimated with a global fire assimilation system based on observed fire radiative power, Biogeosciences, 9(1), 527-554, doi:10.5194/bg-9-527-2012, 2012. 
Kim, H., Collier, S., Ge, X., Xu, J., Sun, Y., Jiang, W., Wang, Y., Herckes, P. and Zhang, Q.: Chemical processing of watersoluble species and formation of secondary organic aerosol in fogs, Atmos. Environ., 200(December 2018), 158-166, doi:10.1016/j.atmosenv.2018.11.062, 2019.

King, S. M., Butcher, A. C., Rosenoern, T., Coz, E., Lieke, K. I., De Leeuw, G., Nilsson, E. D. and Bilde, M.: Investigating primary marine aerosol properties: CCN activity of sea salt and mixed inorganic-organic particles, Environ. Sci. Technol, 46(19), 10405-10412, doi:10.1021/es300574u, 2012.

Knopf, D. A., Alpert, P. A. and Wang, B.: The Role of Organic Aerosol in Atmospheric Ice Nucleation: A Review, ACS Earth

665 Sp. Chem., 2(3), 168-202, doi:10.1021/acsearthspacechem.7b00120, 2018.

Koop, T., Bookhold, J., Shiraiwa, M. and Pöschl, U.: Glass transition and phase state of organic compounds: Dependency on molecular properties and implications for secondary organic aerosols in the atmosphere, Phys. Chem. Chem. Phys, 13(43), 19238-19255, doi:10.1039/c1cp22617g, 2011.

Kristensen, T. B., Müller, T., Kandler, K., Benker, N., Hartmann, M., Prospero, J. M., Wiedensohler, A. and Stratmann, F.:

670 Properties of cloud condensation nuclei $(\mathrm{CCN})$ in the trade wind marine boundary layer of the western North Atlantic, Atmos. Chem. Phys., 16(4), 2675-2688, doi:10.5194/acp-16-2675-2016, 2016.

Kuwata, M. and Martin, S. T.: Phase of atmospheric secondary organic material affects its reactivity, PNAS, 109(43), 1735417359, doi:10.1073/pnas.1209071109, 2012.

Laing, J. R., Jaffe, D. A. and Hee, J. R.: Physical and optical properties of aged biomass burning aerosol from wildfires in

675 Siberia and the Western USA at the Mt. Bachelor Observatory, Atmos. Chem. Phys., 16(23), 15185-15197, doi:10.5194/acp16-15185-2016, 2016.

Laskin, A., Wietsma, T. W., Krueger, B. J. and Grassian, V. H.: Heterogeneous chemistry of individual mineral dust particles with nitric acid: A combined CCSEM/EDX, ESEM, and ICP-MS study, J. Geophys. Res., 110(10), D10208, doi:10.1029/2004JD005206, 2005.

680 Laskin, A., Cowin, J. P. and Iedema, M. J.: Analysis of individual environmental particles using modern methods of electron microscopy and X-ray microanalysis, J. Electron Spectros. Relat. Phenomena, 150(2-3), 260-274, doi:10.1016/j.elspec.2005.06.008, 2006.

Laskin, A., Laskin, J. and Nizkorodov, S. A.: Chemistry of Atmospheric Brown Carbon, Chem. Rev., 115(10), 4335-4382, doi:10.1021/cr5006167, 2015.

685 Lata, N. N., Zhang, B., Schum, S., Mazzoleni, L., Brimberry, R., Marcus, M. A., Cantrell, W. H., Fialho, P. and Mazzoleni, C.: Aerosol Composition, Mixing State, and Phase State of Free Tropospheric Particles and Their Role in Ice Cloud Formation, ACS Earth Sp. Chem., doi:10.1021/acsearthspacechem.1c00315, 2021.

Lee, A. K. Y., Herckes, P., Leaitch, W. R., MacDonald, A. M. and Abbatt, J. P. D.: Aqueous OH oxidation of ambient organic aerosol and cloud water organics: Formation of highly oxidized products, Geophys. Res. Lett., 38(11), 2-6, 690 doi:10.1029/2011GL047439, 2011.

Lee, A. K. Y., Hayden, K. L., Herckes, P., Leaitch, W. R., Liggio, J., MacDonald, A. M. and Abbatt, J. P. D.: Characterization 
of aerosol and cloud water at a mountain site during WACS 2010: Secondary organic aerosol formation through oxidative cloud processing, Atmos. Chem. Phys, 12(15), 7103-7116, doi:10.5194/acp-12-7103-2012, 2012.

Li, Y., Day, D. A., Stark, H., Jimenez, J. L. and Shiraiwa, M.: Predictions of the glass transition temperature and viscosity of organic aerosols from volatility distributions, Atmos. Chem. Phys., 20(13), 8103-8122, doi:10.5194/acp-20-8103-2020, 2020. Li, Y. J., Liu, P. F., Bergoend, C., Bateman, A. P. and Martin, S. T.: Rebounding hygroscopic inorganic aerosol particles: Liquids, gels, and hydrates, Aerosol Sci. Technol., 51(3), 388-396, doi:10.1080/02786826.2016.1263384, 2017.

Lienhard, D. M., Huisman, A. J., Krieger, U. K., Rudich, Y., Marcolli, C., Luo, B. P., Bones, D. L., Reid, J. P., Lambe, A. T., Canagaratna, M. R., Davidovits, P., Onasch, T. B., Worsnop, D. R., Steimer, S. S., Koop, T. and Peter, T.: Viscous organic

700 aerosol particles in the upper troposphere: Diffusivity-controlled water uptake and ice nucleation?, Atmos. Chem. Phys., 15(23), 13599-13613, doi:10.5194/acp-15-13599-2015, 2015.

Liu, P., Li, Y. J., Wang, Y., Bateman, A. P., Zhang, Y., Gong, Z., Bertram, A. K. and Martin, S. T.: Highly Viscous States Affect the Browning of Atmospheric Organic Particulate Matter, ACS Cent. Sci., 4(2), 207-215, doi:10.1021/acscentsci.7b00452, 2018a.

705 Liu, P., Song, M., Zhao, T., Gunthe, S. S., Ham, S., He, Y., Qin, Y. M., Gong, Z., Amorim, J. C., Bertram, A. K. and Martin, S. T.: Resolving the mechanisms of hygroscopic growth and cloud condensation nuclei activity for organic particulate matter, Nat. Commun., 9, 4076, doi:10.1038/s41467-018-06622-2, $2018 \mathrm{~b}$.

Liu, Y., Wu, Z., Wang, Y., Xiao, Y., Gu, F., Zheng, J., Tan, T., Shang, D., Wu, Y., Zeng, L., Hu, M., Bateman, A. P. and Martin, S. T.: Submicrometer Particles Are in the Liquid State during Heavy Haze Episodes in the Urban Atmosphere of

710 Beijing, China, Environ. Sci. Technol. Lett., 4(10), 427-432, doi:10.1021/acs.estlett.7b00352, 2017.

Liu, Y., Wu, Z., Huang, X., Shen, H., Bai, Y., Qiao, K., Meng, X., Hu, W., Tang, M. and He, L.: Aerosol Phase State and Its Link to Chemical Composition and Liquid Water Content in a Subtropical Coastal Megacity, Environ. Sci. Technol., 53(9), 5027-5033, doi:10.1021/acs.est.9b01196, 2019.

Liu, Y., Meng, X., Wu, Z., Huang, D., Wang, H., Chen, J., Chen, J., Zong, T., Fang, X., Tan, T., Zhao, G., Chen, S., Zeng, L.,

715 Guo, S., Huang, X., He, L., Zeng, L. and Hu, M.: The particle phase state during the biomass burning events, Sci. Total Environ., 792, 148035, doi:10.1016/j.scitotenv.2021.148035, 2021.

Malecha, K. T. and Nizkorodov, S. A.: Photodegradation of Secondary Organic Aerosol Particles as a Source of Small, Oxygenated Volatile Organic Compounds, Environ. Sci. Technol., 50(18), 9990-9997, doi:10.1021/acs.est.6b02313, 2016.

Marinoni, A., Cristofanelli, P., Calzolari, F., Roccato, F., Bonafè, U. and Bonasoni, P.: Continuous measurements of aerosol physical parameters at the Mt. Cimone GAW Station (2165 m asl, Italy), Sci. Total Environ., 391(2-3), 241-251, doi:10.1016/j.scitotenv.2007.10.004, 2008.

Marshall, F. H., Miles, R. E. H., Song, Y. C., Ohm, P. B., Power, R. M., Reid, J. P. and Dutcher, C. S.: Diffusion and reactivity in ultraviscous aerosol and the correlation with particle viscosity, Chem. Sci., 7(2), 1298-1308, doi:10.1039/c5sc03223g, 2016. Moffet, R. C., Henn, T., Laskin, A. and Gilles, M. K.: Automated chemical analysis of internally mixed aerosol particles using X-ray spectromicroscopy at the carbon K-edge, Anal. Chem., 82(19), 7906-7914, doi:10.1021/ac1012909, 2010. 
Moffet, R. C., Tivanski, A. V and Gilles, M. K.: Scanning Transmission X-ray Microscopy: Applications in Atmospheric Aerosol Research, in Fundamentals and Applications in Aerosol Spectroscopy, edited by R. Signorell and J. P. Reid, p. 419-462, Taylor and Francis Books, Inc., Boca Raton, FL., 2011.

Moffet, R. C., Rödel, T. C., Kelly, S. T., Yu, X. Y., Carroll, G. T., Fast, J., Zaveri, R. A., Laskin, A. and Gilles, M. K.: Spectro-

730 microscopic measurements of carbonaceous aerosol aging in Central California, Atmos. Chem. Phys., 13(20), 10445-10459, doi:10.5194/acp-13-10445-2013, 2013.

Moosmüller, H., Chakrabarty, R. K. and Arnott, W. P.: Aerosol light absorption and its measurement: A review, J. Quant. Spectrosc. Radiat. Transf., 110(11), 844-878, doi:10.1016/j.jqsrt.2009.02.035, 2009.

Motos, G., Corbin, J. C., Schmale, J., Modini, R. L., Bertò, M., Kupiszewski, P., Baltensperger, U. and Gysel-Beer, M.: Black

735 Carbon Aerosols in the Lower Free Troposphere are Heavily Coated in Summer but Largely Uncoated in Winter at Jungfraujoch in the Swiss Alps, Geophys. Res. Lett., 47(14), 1-10, doi:10.1029/2020GL088011, 2020.

Murray, B. J., Wilson, T. W., Dobbie, S., Cui, Z., Al-Jumur, S. M. R. K., Möhler, O., Schnaiter, M., Wagner, R., Benz, S., Niemand, M., Saathoff, H., Ebert, V., Wagner, S. and Kärcher, B.: Heterogeneous nucleation of ice particles on glassy aerosols under cirrus conditions, Nat. Geosci., 3(4), 233-237, doi:10.1038/ngeo817, 2010.

740 North, G. R., Zhang, F. and Pyle, J.: Encyclopedia of Atmospheric Sciences, 2nd ed., edited by G. R. North, J. Pyle, and F. Zhang, Academic Press, Cambridge, MA., 2014.

O’Brien, R. E., Neu, A., Epstein, S. A., Macmillan, A. C., Wang, B., Kelly, S. T., Nizkorodov, S. A., Laskin, A., Moffet, R. C. and Gilles, M. K.: Physical properties of ambient and laboratory- generated secondary organic aerosol, Geophys. Res. Lett., 41, 4347-4353, doi:10.1002/2014GL060219.Received, 2014.

745 Olivier, J. G. J. and Berdowski, J. J. M.: Global emission sources and sinks, in The Climate System, pp. 33-78., 2001.

Owen, R. C. and Honrath, R. E.: Technical note: a new method for the Lagrangian tracking of pollution plumes from source to receptor using gridded model output, Atmos. Chem. Phys., 9(7), 2577-2595, doi:10.5194/acp-9-2577-2009, 2009.

Pajunoja, A., Hu, W., Leong, Y. J., Taylor, N. F., Miettinen, P., Palm, B. B., Mikkonen, S., Collins, D. R., Jimenez, J. L. and Virtanen, A.: Phase state of ambient aerosol linked with water uptake and chemical aging in the southeastern US, Atmos.

750 Chem. Phys., 16(17), 11163-11176, doi:10.5194/acp-16-11163-2016, 2016.

Pan, X., Underwood, J. S., Xing, J., Mang, S. A. and Nizkorodov, S. A.: Photodegradation of secondary organic aerosol generated from limonene oxidation by ozone studied with chemical ionization mass spectrometry, Atmos. Chem. Phys., 9, 3851-3865, 2009.

Pham, D. Q., O’Brien, R., Fraund, M., Bonanno, D., Laskina, O., Beall, C., Moore, K. A., Forestieri, S., Wang, X., Lee, C.,

755 Sultana, C., Grassian, V., Cappa, C. D., Prather, K. A. and Moffet, R. C.: Biological Impacts on Carbon Speciation and Morphology of Sea Spray Aerosol, ACS Earth Sp. Chem., 1(9), 551-561, doi:10.1021/acsearthspacechem.7b00069, 2017.

Pöschl, U. and Shiraiwa, M.: Multiphase Chemistry at the Atmosphere-Biosphere Interface Influencing Climate and Public Health in the Anthropocene, Chem. Rev., 115(10), 4440-4475, doi:10.1021/cr500487s, 2015a.

Pöschl, U. and Shiraiwa, M.: Multiphase Chemistry at the Atmosphere-Biosphere Interface Influencing Climate and Public 
760 Health in the Anthropocene, Chem. Rev., 115(10), 4440-4475, doi:10.1021/cr500487s, 2015b.

Posfai, M., Gelencser, A., Simonics, R., Arato, K., Li, J., Hobbs, P. V. and Buseck, P. R.: Atmospheric tar balls: Particles from biomass and biofuel burning, J. Geophys. Res., 109, D06213, doi:10.1029/2003JD004169, 2004.

Power, R. M., Simpson, S. H., Reid, J. P. and Hudson, A. J.: The transition from liquid to solid-like behaviour in ultrahigh viscosity aerosol particles, Chem. Sci., 4(6), 2597-2604, doi:10.1039/c3sc50682g, 2013.

765 Pringle, K. J., Tost, H., Pozzer, A., Pöschl, U. and Lelieveld, J.: Global distribution of the effective aerosol hygroscopicity parameter for CCN activation, Atmos. Chem. Phys., 10(12), 5241-5255, doi:10.5194/acp-10-5241-2010, 2010.

Rasool, Q. Z., Shrivastava, M., Octaviani, M., Zhao, B., Gaudet, B. and Liu, Y.: Modeling Volatility-Based Aerosol Phase State Predictions in the Amazon Rainforest, ACS Earth Sp. Chem., 5, 2910-2924, doi:10.1021/acsearthspacechem.1c00255, 2021.

770 Raveh-Rubin, S.: Dry intrusions: Lagrangian climatology and dynamical impact on the planetary boundary layer, J. Clim., 30(17), 6661-6682, doi:10.1175/JCLI-D-16-0782.1, 2017.

Raveh-Rubin, S. and Catto, J. L.: Climatology and dynamics of the link between dry intrusions and cold fronts during winter, Part II: Front-centred perspective, Clim. Dyn., 53(3-4), 1893-1909, doi:10.1007/s00382-019-04793-2, 2019.

Reid, J. P., Bertram, A. K., Topping, D. O., Laskin, A., Martin, S. T., Petters, M. D., Pope, F. D. and Rovelli, G.: The viscosity

775 of atmospherically relevant organic particles, Nat. Commun., 9, 956, doi:10.1038/s41467-018-03027-z, 2018.

Renbaum-Wolff, L., Grayson, J. W., Bateman, A. P., Kuwata, M., Sellier, M., Murray, B. J., Shilling, J. E., Martin, S. T. and Bertram, A. K.: Viscosity of a-pinene secondary organic material and implications for particle growth and reactivity, PNAS, 110(20), 8014-8019, doi:10.1073/pnas.1219548110, 2013.

Riemer, N., Ault, A. P., West, M., Craig, R. L. and Curtis, J. H.: Aerosol Mixing State: Measurements, Modeling, and Impacts,

780 Rev. Geophys., 57(2), 187-249, doi:10.1029/2018RG000615, 2019.

Rinaldi, M., Gilardoni, S., Paglione, M., Sandrini, S., Fuzzi, S., Massoli, P., Bonasoni, P., Cristofanelli, P., Marinoni, A., Poluzzi, V. and Decesari, S.: Organic aerosol evolution and transport observed at Mt. Cimone (2165 m a.s.1.), Italy, during the PEGASOS campaign, Atmos. Chem. Phys., 15(19), 11327-11340, doi:10.5194/acp-15-11327-2015, 2015.

Rose, C., Sellegri, K., Moreno, I., Velarde, F., Ramonet, M., Weinhold, K., Krejci, R., Andrade, M., Wiedensohler, A., Ginot,

785 P. and Laj, P.: CCN production by new particle formation in the free troposphere, Atmos. Chem. Phys., 17(2), 1529-1541, doi:10.5194/acp-17-1529-2017, 2017.

Rovelli, G., Song, Y. C., MacLean, A. M., Topping, D. O., Bertram, A. K. and Reid, J. P.: Comparison of Approaches for Measuring and Predicting the Viscosity of Ternary Component Aerosol Particles, Anal. Chem., 91(8), 5074-5082, doi:10.1021/acs.analchem.8b05353, 2019.

790 Saleh, R.: From Measurements to Models: Toward Accurate Representation of Brown Carbon in Climate Calculations, Curr Pollut. Rep, (706), doi:doi.org/10.1007/s40726-020-00139-3, 2020.

Saukko, E., Lambe, A. T., Massoli, P., Koop, T., Wright, J. P., Croasdale, D. R., Pedernera, D. A., Onasch, T. B., Laaksonen, A., Davidovits, P., Worsnop, D. R. and Virtanen, A.: Humidity-dependent phase state of SOA particles from biogenic and 
anthropogenic precursors, Atmos. Chem. Phys., 12(16), 7517-7529, doi:10.5194/acp-12-7517-2012, 2012.

795 Schill, G. P. and Tolbert, M. A.: Heterogeneous ice nucleation on simulated sea-spray aerosol using Raman microscopy, J. Phys. Chem. C, 118(50), 29234-29241, doi:10.1021/jp505379j, 2014.

Schmale, J., Henning, S., Henzing, B., Keskinen, H., Sellegri, K., Ovadnevaite, J., Bougiatioti, A., Kalivitis, N., Stavroulas, I., Jefferson, A., Park, M. and Schlag, P.: Data Descriptor : Collocated observations of cloud condensation nuclei , particle size distributions, and chemical composition, Sci. DATA, 3, 170003, 2017.

800 Schmedding, R., Rasool, Q. Z., Zhang, Y., Pye, H. O. T., Zhang, H., Chen, Y., Surratt, J. D., Lopez-Hilfiker, F. D., Thornton, J. A., Goldstein, A. H. and Vizuete, W.: Predicting secondary organic aerosol phase state and viscosity and its effect on multiphase chemistry in a regional-scale air quality model, Atmos. Chem. Phys., 20(13), 8201-8225, doi:10.5194/acp-208201-2020, 2020.

Schmeissner, T., Krejci, R., Ström, J., Birmili, W., Wiedensohler, A., Hochschild, G., Gross, J., Hoffmann, P. and Calderon,

805 S.: Analysis of number size distributions of tropical free tropospheric aerosol particles observed at Pico Espejo (4765 m a.s.1.), Venezuela, Atmos. Chem. Phys., 11(7), 3319-3332, doi:10.5194/acp-11-3319-2011, 2011.

Schulze, B. C., Charan, S. M., Kenseth, C. M., Kong, W., Bates, K. H., Williams, W., Metcalf, A. R., Jonsson, H. H., Woods, R., Sorooshian, A., Flagan, R. C. and Seinfeld, J. H.: Characterization of Aerosol Hygroscopicity Over the Northeast Pacific Ocean: Impacts on Prediction of $\mathrm{CCN}$ and Stratocumulus Cloud Droplet Number Concentrations, Earth Sp. Sci., 7(7), e2020EA001098, doi:10.1029/2020ea001098.Characterization, 2020.

Schum, S. K., Zhang, B., Dzepina, K., Fialho, P., Mazzoleni, C. and Mazzoleni, L. R.: Molecular and physical characteristics of aerosol at a remote free troposphere site: Implications for atmospheric aging, Atmos. Chem. Phys., 18(19), 14017-14036, doi:10.5194/acp-18-14017-2018, 2018.

Seibert, P. and Frank, A.: Source-receptor matrix calculation with a Lagrangian particle dispersion model in backward mode,

815 Atmos. Chem. Phys., 4(1), 51-63, doi:10.5194/acp-4-51-2004, 2004.

Seinfeld, J. H. and Pandis, S. N.: Atmospheric Chemistry and Physics: From Air Pollution to Climate Change, 2nd ed., John Wiley \& Sons, Inc., Hoboken, New Jersey., 2006.

Seinfeld, J. H., Bretherton, C., Carslaw, K. S., Coe, H., DeMott, P. J., Dunlea, E. J., Feingold, G., Ghan, S., Guenther, A. B., Kahn, R., Kraucunas, I., Kreidenweis, S. M., Molina, M. J., Nenes, A., Penner, J. E., Prather, K. A., Ramanathan, V.,

820 Ramaswamy, V., Rasch, P. J., Ravishankara, A. R., Rosenfeld, D., Stephens, G. and Wood, R.: Improving our fundamental understanding of the role of aerosol-cloud interactions in the climate system, PNAS, 113(21), 5781-5790, doi:10.1073/pnas.1514043113, 2016.

Sharma, N., China, S., Bhandari, J., Gorkowski, K., Dubey, M., Zaveri, R. A. and Mazzoleni, C.: Physical Properties of Aerosol Internally Mixed With Soot Particles in a Biogenically Dominated Environment in California, Geophys. Res. Lett., 45(20),

825 11,473-11,482, doi:10.1029/2018GL079404, 2018.

Shiraiwa, M., Li, Y., Tsimpidi, A. P., Karydis, V. A., Berkemeier, T., Pandis, S. N., Lelieveld, J., Koop, T. and Pöschl, U.: Global distribution of particle phase state in atmospheric secondary organic aerosols, Nat. Commun., 8, 15002, 
doi:10.1038/ncomms15002, 2017.

Shrivastava, M., Lou, S., Zelenyuk, A., Easter, R. C., Corley, R. A., Thrall, B. D., Rasch, P. J., Fast, J. D., Simonich, S. L. M.,

830 Shen, H. and Tao, S.: Global long-range transport and lung cancer risk from polycyclic aromatic hydrocarbons shielded by coatings of organic aerosol, PNAS, 114(6), 1246-1251, doi:10.1073/pnas.1702221114, 2017.

Siebert, H., Szodry, K. E., Egerer, U., Wehner, B., Henning, S., Chevalier, K., Lückerath, J., Welz, O., Weinhold, K., Lauermann, F., Gottschalk, M., Ehrlich, A., Wendisch, M., Fialho, P., Roberts, G., Allwayin, N., Schum, S., Shaw, R. A., Mazzoleni, C., Mazzoleni, L., Nowak, J. L., Malinowski, S. P., Karpinska, K., Kumala, W., Czyzewska, D., Luke, E. P.,

835 Kollias, P., Wood, R. and Mellado, J. P.: Observations of aerosol, cloud, turbulence, and radiation properties at the top of the Marine Boundary Layer over the Eastern North Atlantic Ocean, Bull. Am. Meteorol. Soc., 102(1), E123-E147, doi:10.1175/BAMS-D-19-0191.1, 2021.

Slade, J. H., Ault, A. P., Bui, A. T., Ditto, J. C., Lei, Z., Bondy, A. L., Olson, N. E., Cook, R. D., Desrochers, S. J., Harvey, R. M., Erickson, M. H., Wallace, H. W., Alvarez, S. L., Flynn, J. H., Boor, B. E., Petrucci, G. A., Gentner, D. R., Griffin, R. J.

840 and Shepson, P. B.: Bouncier Particles at Night: Biogenic Secondary Organic Aerosol Chemistry and Sulfate Drive Diel Variations in the Aerosol Phase in a Mixed Forest, Environ. Sci. Technol., 53(9), 4977-4987, doi:10.1021/acs.est.8b07319, 2019.

Song, Y. C., Lilek, J., Lee, J. B., Chan, M. N., Wu, Z., Zuend, A. and Song, M.: Viscosity and phase state of aerosol particles consisting of sucrose mixed with inorganic salts, Atmos. Chem. Phys., 21(13), 10215-10228, doi:10.5194/acp-21-10215-2021,

8452021.

Sorooshian, A., Varutbangkul, V., Brechtel, F. J., Ervens, B., Feingold, G., Bahreini, R., Murphy, S. M., Holloway, J. S., Atlas, E. L., Buzorius, G., Jonsson, H., Flagan, R. C. and Seinfeld, J. H.: Oxalic acid in clear and cloudy atmospheres: Analysis of data from International Consortium for Atmospheric Research on Transport and Transformation 2004, J. Geophys. Res., 111(23), 1-17, doi:10.1029/2005JD006880, 2006.

850 Sorooshian, A., Lu, M. L., Brechtel, F. J., Jonsson, H., Feingold, G., Flagan, R. C. and Seinfeld, J. H.: On the source of organic acid aerosol layers above clouds, Environ. Sci. Technol., 41(13), 4647-4654, doi:10.1021/es0630442, 2007.

Stohl, A., Forster, C., Frank, A., Seibert, P. and Wotawa, G.: Technical note: The Lagrangian particle dispersion model FLEXPART version 6.2, Atmos. Chem. Phys., 5(9), 2461-2474, doi:10.5194/acp-5-2461-2005, 2005.

Sumlin, B. J., Pandey, A., Walker, M. J., Pattison, R. S., Williams, B. J. and Chakrabarty, R. K.: Atmospheric Photooxidation

855 Diminishes Light Absorption by Primary Brown Carbon Aerosol from Biomass Burning, Environ. Sci. Technol. Lett, 4, 540-545, doi:10.1021/acs.estlett.7b00393, 2017.

Sun, J., Hermann, M., Yuan, Y., Birmili, W., Collaud Coen, M., Weinhold, K., Madueño, L., Poulain, L., Tuch, T., Ries, L., Sohmer, R., Couret, C., Frank, G., Brem, B. T., Gysel-Beer, M., Ma, N. and Wiedensohler, A.: Long-term trends of black carbon and particle number concentration in the lower free troposphere in Central Europe, Environ. Sci. Eur., 33(1), 860 doi:10.1186/s12302-021-00488-w, 2021.

Sun, Y., Zhang, Q., MacDonald, A. M., Hayden, K., Li, S. M., Liggio, J., Liu, P. S. K., Anlauf, K. G., Leaitch, W. R., Steffen, 
A., Cubison, M., Worsnop, D. R., Van Donkelaar, A. and Martin, R. V.: Size-resolved aerosol chemistry on Whistler Mountain, Canada with a high-resolution aerosol mass spectrometer during INTEX-B, Atmos. Chem. Phys., 9(9), 3095-3111, doi:10.5194/acp-9-3095-2009, 2009.

865 Tomlin, J. M., Jankowski, K. A., Rivera-adorno, F. A., Fraund, M., Stirm, B. H., Kaeser, R., Eakins, G. S., Mo, R. C., Shepson, P. B. and Laskin, A.: Chemical Imaging of Fine Mode Atmospheric Particles Collected from a Research Aircraft over Agricultural Fields, ACS Earth Sp. Chem., 4(2171-2184), doi:10.1021/acsearthspacechem.0c00172, 2020.

Tomlin, J. M., Jankowski, K. A., Veghte, D. P., Wang, P., Fraund, M., Weis, J., Zheng, G., Wang, Y., Rivera-adorno, F., Raveh-rubin, S., Knopf, D. A., Wang, J., Gilles, M. K. and Moffet, R. C.: Impact of dry intrusion events on the composition

870 and mixing state of particles during the winter Aerosol and Cloud Experiment in the Eastern North Atlantic (ACE-ENA ), Atmos. Chem. Phys., 21, 18123-18146, 2021.

Val Martin, M., Honrath, R. E., Owen, R. C. and Lapina, K.: Large-scale impacts of anthropogenic pollution and boreal wildfires on the nitrogen oxides over the central North Atlantic region, J. Geophys. Res., 113(17), 1-11, doi:10.1029/2007JD009689, 2008a.

875 Val Martin, M., Honrath, R. E., Owen, R. C. and Li, Q. B.: Seasonal variation of nitrogen oxides in the central North Atlantic lower free troposhere, J. Geophys. Res., 113(17), 1-15, doi:10.1029/2007JD009688, 2008b.

Virtanen, A., Joutsensaari, J., Koop, T., Kannosto, J., Yli-Pirilä, P., Leskinen, J., Mäkelä, J. M., Holopainen, J. K., Pöschl, U., Kulmala, M., Worsnop, D. R. and Laaksonen, A.: An amorphous solid state of biogenic secondary organic aerosol particles, Nature, 467(7317), 824-827, doi:10.1038/nature09455, 2010.

880 Virtanen, A., Kannosto, J., Kuuluvainen, H., Arffman, A., Joutsensaari, J., Saukko, E., Hao, L., Yli-Pirilä, P., Tiitta, P., Holopainen, J. K., Keskinen, J., Worsnop, D. R., Smith, J. N. and Laaksonen, A.: Bounce behavior of freshly nucleated biogenic secondary organic aerosol particles, Atmos. Chem. Phys., 11(16), 8759-8766, doi:10.5194/acp-11-8759-2011, 2011. Wang, B., O’Brien, R. E., Kelly, S. T., Shilling, J. E., Mo, R. C., Gilles, M. K. and Laskin, A.: Reactivity of Liquid and Semisolid Secondary Organic Carbon with Chloride and Nitrate in Atmospheric Aerosols, J. Phys. Chem. A, 119, 4498-4508, 2015.

Wang, B., Harder, T. H., Kelly, S. T., Piens, D. S., China, S., Kovarik, L., Keiluweit, M., Arey, B. W., Gilles, M. K. and Laskin, A.: Airborne soil organic particles generated by precipitation, Nat. Geosci., 9(6), 433-437, doi:10.1038/ngeo2705, 2016.

Wang, J., Cubison, M. J., Aiken, A. C., Jimenez, J. L. and Collins, D. R.: The importance of aerosol mixing state and sizeresolved composition on $\mathrm{CCN}$ concentration and the variation of the importance with atmospheric aging of aerosols, Atmos. Chem. Phys., 10(15), 7267-7283, doi:10.5194/acp-10-7267-2010, 2010.

Weiss-Penzias, P., Jaffe, D. A., Swartzendruber, P., Dennison, J. B., Chand, D., Hafner, W. and Prestbo, E.: Observations of Asian air pollution in the free troposphere at Mount Bachelor Observatory during the spring of 2004, J. Geophys. Res., 111(10), 1-15, doi:10.1029/2005JD006522, 2006.

895 De Wekker, S. F. J. and Kossmann, M.: Convective boundary layer heights over mountainous terrain—A review of concepts, 
Front. Earth Sci., 3(December), 1-22, doi:10.3389/feart.2015.00077, 2015.

Yamasoe, M. A., Artaxo, P., Miguel, A. H. and Allen, A. G.: Chemical composition of aerosol particles from direct emissions of vegetation fires in the Amazon Basin: Water-soluble species and trace elements, Atmos. Environ., 34(10), 1641-1653, doi:10.1016/S1352-2310(99)00329-5, 2000.

900 Yu, J. Z., Huang, X. F., Xu, J. and Hu, M.: When aerosol sulfate goes up, so does oxalate: Implication for the formation mechanisms of oxalate, Environ. Sci. Technol., 39(1), 128-133, doi:10.1021/es049559f, 2005.

Zhang, B., Owen, R. C., Perlinger, J. A., Kumar, A., Wu, S., Val Martin, M., Kramer, L., Helmig, D. and Honrath, R. E.: A semi-Lagrangian view of ozone production tendency in North American outflow in the summers of 2009 and 2010, Atmos. Chem. Phys., 14(5), 2267-2287, doi:10.5194/acp-14-2267-2014, 2014.

905 Zhang, B., Owen, R. C., Perlinger, J. A., Helmig, D., Val Martin, M., Kramer, L., Mazzoleni, L. R. and Mazzoleni, C.: Tenyear chemical signatures associated with long-range transport observed in the free troposphere over the central North Atlantic, Elem. Sci. Anth., 5(8), 194, doi:10.1525/elementa.194, 2017.

Zhou, S., Collier, S., Jaffe, D. A. and Zhang, Q.: Free Tropospheric Aerosols at the Mt. Bachelor Observatory: More Oxidized and Higher Sulfate Content Compared to Boundary Layer Aerosols, Atmos. Chem. Phys., 19, 1571-1585, doi:10.5194/acp-

$910 \quad 2018-821,2019$.

Zufall, M. J. and Davidson, C. I.: Dry Deposition of Particles from the Atmosphere, in Air Pollution in the Ural Mountains: Environmental, Health and Policy Aspects, edited by I. Linkov and R. Wilson, pp. 55-56, Springer, Dordrecht., 1998. 
Table 1. Summary of Pico 2014, 2015, and 2017 samples. S3 and S4 samples were collected on stage 3 (cut-off size: >0.15 $915 \mu \mathrm{m}$ ) and stage 4 (cut-off size: $>0.05 \mu \mathrm{m}$ ) of an impactor, respectively. Additional information of sampling time and conditions and fractions of different species in each sample based on CCSEM-EDX and STXM-NEXAFS is listed in Tables S1 and S2.

\begin{tabular}{|c|c|c|c|c|c|c|c|c|c|c|c|c|c|}
\hline \multirow{2}{*}{$\begin{array}{l}\text { Sample } \\
\text { ID }\end{array}$} & \multirow[t]{2}{*}{ Air mass pattern } & \multicolumn{6}{|c|}{ Contribution of source } & \multirow{2}{*}{$\begin{array}{l}\text { Average } \\
\text { aging time } \\
\text { (days) }\end{array}$} & \multirow{2}{*}{$\begin{array}{l}\% \text { of } \\
\text { solid } \\
\text { partic } \\
\text { le }\end{array}$} & \multirow{2}{*}{$\begin{array}{l}\% \text { of } \\
\text { semisol } \\
\text { id } \\
\text { particle }\end{array}$} & \multirow{2}{*}{$\begin{array}{l}\text { \% of } \\
\text { liqui } \\
d \\
\text { parti } \\
\text { cles }\end{array}$} & \multirow[b]{2}{*}{$\begin{array}{l}\# \% \quad \text { of } \\
\text { particle } \\
\text { has } \\
\text { aspect } \\
\text { ratio } \geq \\
4\end{array}$} & \multirow[b]{2}{*}{$\begin{array}{l}\text { element } \\
\text { percent } \\
\text { age of } \\
\mathrm{Na}, \\
\mathrm{Mg}, \mathrm{Al} \text {, } \\
\mathrm{P}, \quad \mathrm{S} \text {, } \\
\text { and } \mathrm{K}\end{array}$} \\
\hline & & $\begin{array}{l}\text { North } \\
\text { America }\end{array}$ & Europe & Asia & $\begin{array}{l}\text { South } \\
\text { America }\end{array}$ & $\begin{array}{l}\text { Afric } \\
\text { a }\end{array}$ & Wildfire & & & & & & \\
\hline $\begin{array}{l}\text { SA1 } \\
(2014)\end{array}$ & North America & $48.9 \%$ & $8.4 \%$ & $0.0 \%$ & $13.7 \%$ & $0.3 \%$ & $28.6 \%$ & 16.4 & $\begin{array}{l}29.8 \\
\%\end{array}$ & $23.1 \%$ & $\begin{array}{l}47.1 \\
\%\end{array}$ & $0.0 \%$ & $\begin{array}{l}5.8 \pm 6.4 \\
\%\end{array}$ \\
\hline $\begin{array}{l}\text { SA2 } \\
(2014)\end{array}$ & North America & $41.7 \%$ & $0.2 \%$ & $0.9 \%$ & $0.1 \%$ & $\begin{array}{l}26.2 \\
\%\end{array}$ & $31.0 \%$ & 16.2 & $0.0 \%$ & $1.9 \%$ & $\begin{array}{l}98.1 \\
\%\end{array}$ & $84.6 \%$ & $\begin{array}{l}15.9 \pm 1 \\
9.9 \%\end{array}$ \\
\hline $\begin{array}{l}\text { SA3 } \\
(2014)\end{array}$ & North America & $49.0 \%$ & $0.0 \%$ & $0.4 \%$ & $0.1 \%$ & $1.1 \%$ & $49.4 \%$ & 16.0 & $1.0 \%$ & $1.0 \%$ & $\begin{array}{l}98.0 \\
\%\end{array}$ & $68.6 \%$ & $\begin{array}{l}9.1 \pm 7.1 \\
\%\end{array}$ \\
\hline $\begin{array}{l}\text { S1 } \\
(2015)\end{array}$ & North America & $55.8 \%$ & $0.0 \%$ & $2.1 \%$ & $0.0 \%$ & $0.0 \%$ & $42.2 \%$ & 15.7 & $4.5 \%$ & $28.5 \%$ & $\begin{array}{l}67.0 \\
\%\end{array}$ & $20.0 \%$ & $\begin{array}{l}1.7 \pm 3.3 \\
\%\end{array}$ \\
\hline $\begin{array}{l}\text { S2 } \\
(2015)\end{array}$ & $\begin{array}{ll}\text { North America }+ \\
\text { Africa }\end{array}$ & $83.7 \%$ & $0.0 \%$ & $7.2 \%$ & $1.7 \%$ & $3.3 \%$ & $4.1 \%$ & 12.2 & $1.0 \%$ & $5.5 \%$ & $\begin{array}{l}93.5 \\
\%\end{array}$ & $29.0 \%$ & $\begin{array}{l}6.1 \pm 7.2 \\
\%\end{array}$ \\
\hline $\begin{array}{l}\text { S3 } \\
(2015)\end{array}$ & $\begin{array}{lll}\text { North America }+ \\
\text { Arctic }\end{array}$ & $79.2 \%$ & $0.2 \%$ & $1.8 \%$ & $0.1 \%$ & $0.0 \%$ & $18.7 \%$ & 10.5 & $0.5 \%$ & $1.5 \%$ & $\begin{array}{l}98.0 \\
\%\end{array}$ & $53.5 \%$ & $\begin{array}{l}2.8 \pm 7.0 \\
\%\end{array}$ \\
\hline $\begin{array}{l}\text { S4 } \\
(2015)\end{array}$ & $\begin{array}{lll}\text { North } & \text { America } & + \\
\text { Arctic } & & \end{array}$ & $8.3 \%$ & $0.1 \%$ & $0.9 \%$ & $0.0 \%$ & $0.0 \%$ & $90.6 \%$ & 12.3 & $0.0 \%$ & $1.5 \%$ & $\begin{array}{l}98.5 \\
\%\end{array}$ & $90.5 \%$ & $\begin{array}{l}1.9 \pm 3.5 \\
\%\end{array}$ \\
\hline $\begin{array}{l}\text { S5 } \\
(2015)\end{array}$ & $\begin{array}{lll}\text { North } & \text { America } & + \\
\text { Africa } & & \end{array}$ & $37.9 \%$ & $0.0 \%$ & $1.4 \%$ & $3.1 \%$ & $4.7 \%$ & $52.9 \%$ & 16.1 & $0.5 \%$ & $5.5 \%$ & $\begin{array}{l}94.0 \\
\%\end{array}$ & $45.5 \%$ & $\begin{array}{l}4.4 \pm 5.7 \\
\%\end{array}$ \\
\hline $\begin{array}{l}\text { S6 } \\
(2015)\end{array}$ & North America & $59.3 \%$ & $0.4 \%$ & $0.0 \%$ & $10.4 \%$ & $4.7 \%$ & $25.2 \%$ & 17.1 & $1.5 \%$ & $42.0 \%$ & $\begin{array}{l}56.5 \\
\%\end{array}$ & $15.0 \%$ & $\begin{array}{l}3.3 \pm 4.5 \\
\%\end{array}$ \\
\hline $\begin{array}{l}\text { S3-1 } \\
(2017)\end{array}$ & $\begin{array}{l}\text { Recirculation over the } \\
\text { North Atlantic Ocean }\end{array}$ & $80.3 \%$ & $0.6 \%$ & $\begin{array}{l}11.3 \\
\%\end{array}$ & $2.7 \%$ & $0.0 \%$ & $5.1 \%$ & 13.3 & $8.3 \%$ & $15.5 \%$ & $\begin{array}{l}76.1 \\
\%\end{array}$ & $12.5 \%$ & $\begin{array}{l}2.2 \pm 1.6 \\
\%\end{array}$ \\
\hline $\begin{array}{l}\text { S3-2 } \\
(2017)\end{array}$ & $\begin{array}{l}\text { North America with } \\
\text { contribution from } \\
\text { Africa }\end{array}$ & $47.3 \%$ & $0.0 \%$ & $0.0 \%$ & $32.0 \%$ & $\begin{array}{l}17.1 \\
\%\end{array}$ & $3.6 \%$ & 12.8 & $0.0 \%$ & $6.7 \%$ & $\begin{array}{l}93.3 \\
\%\end{array}$ & $30.9 \%$ & $\begin{array}{l}1.3 \pm 1.4 \\
\%\end{array}$ \\
\hline $\begin{array}{l}\text { S3-3 } \\
(2017)\end{array}$ & $\begin{array}{lr}\text { North } & \text { America }+ \\
\text { South } & \text { America }+ \\
\text { Africa } & \end{array}$ & $31.0 \%$ & $0.0 \%$ & $0.0 \%$ & $50.2 \%$ & $\begin{array}{l}16.0 \\
\%\end{array}$ & $2.9 \%$ & 12.7 & $2.0 \%$ & $4.7 \%$ & $\begin{array}{l}93.3 \\
\%\end{array}$ & $35.3 \%$ & $\begin{array}{l}1.2 \pm 1.8 \\
\%\end{array}$ \\
\hline $\begin{array}{l}\text { S3-4 } \\
(2017)\end{array}$ & $\begin{array}{l}\text { North America }+ \\
\text { Europe }+ \text { Asia }\end{array}$ & $20.5 \%$ & $0.9 \%$ & $\begin{array}{l}63.3 \\
\%\end{array}$ & $0.6 \%$ & $0.6 \%$ & $14.2 \%$ & 12.5 & $3.1 \%$ & $3.1 \%$ & $\begin{array}{l}93.8 \\
\%\end{array}$ & $32.9 \%$ & $\begin{array}{l}1.4 \pm 1.5 \\
\%\end{array}$ \\
\hline $\begin{array}{l}\text { S4-1 } \\
(2017)\end{array}$ & North America & $69.7 \%$ & $0.3 \%$ & $9.4 \%$ & $0.0 \%$ & $0.0 \%$ & $20.5 \%$ & 14.0 & $\begin{array}{l}11.0 \\
\%\end{array}$ & $9.0 \%$ & $\begin{array}{l}80.0 \\
\%\end{array}$ & $31.5 \%$ & $\begin{array}{l}1.3 \pm 1.0 \\
\%\end{array}$ \\
\hline
\end{tabular}


https://doi.org/10.5194/acp-2022-84

Preprint. Discussion started: 11 February 2022

(c) Author(s) 2022. CC BY 4.0 License.

(c) (1)

Atmospheric

Chemistry

and Physics

Discussions

\begin{tabular}{|l|l|l|l|l|l|l|l|l|l|l|l|l|l|}
\hline $\begin{array}{l}\text { S4-2 } \\
(2017)\end{array}$ & Asia + Arctic & $1.2 \%$ & $3.1 \%$ & $\begin{array}{l}60.5 \\
\%\end{array}$ & $0.0 \%$ & $0.0 \%$ & $35.2 \%$ & 14.2 & $5.8 \%$ & $\begin{array}{l}13.1 \% \\
81.0\end{array}$ & $\begin{array}{l}8.0 \% \\
\%\end{array}$ & $\begin{array}{l}1.3 \pm 0.8 \\
\%\end{array}$ \\
\hline $\begin{array}{l}\text { S4-3 } \\
(2017)\end{array}$ & North America & $22.4 \%$ & $0.5 \%$ & $\begin{array}{l}25.1 \\
\%\end{array}$ & $0.0 \%$ & $0.0 \%$ & $52.0 \%$ & 13.1 & $\begin{array}{l}10.2 \\
\%\end{array}$ & $\begin{array}{l}5.6 \% \\
84.3\end{array}$ & $\begin{array}{l}52.3 \% \\
\%\end{array}$ & $\begin{array}{l}1.6 \pm 1.1 \\
\%\end{array}$ \\
\hline $\begin{array}{l}\text { S4-4 } \\
(2017)\end{array}$ & North America & $48.4 \%$ & $0.1 \%$ & $7.1 \%$ & $0.0 \%$ & $0.1 \%$ & $44.3 \%$ & 11.3 & $\begin{array}{l}15.5 \\
\%\end{array}$ & $5.3 \%$ & $\begin{array}{l}79.1 \\
\%\end{array}$ & $\begin{array}{l}53.5 \% \\
\%\end{array}$ \\
\hline
\end{tabular}

920 

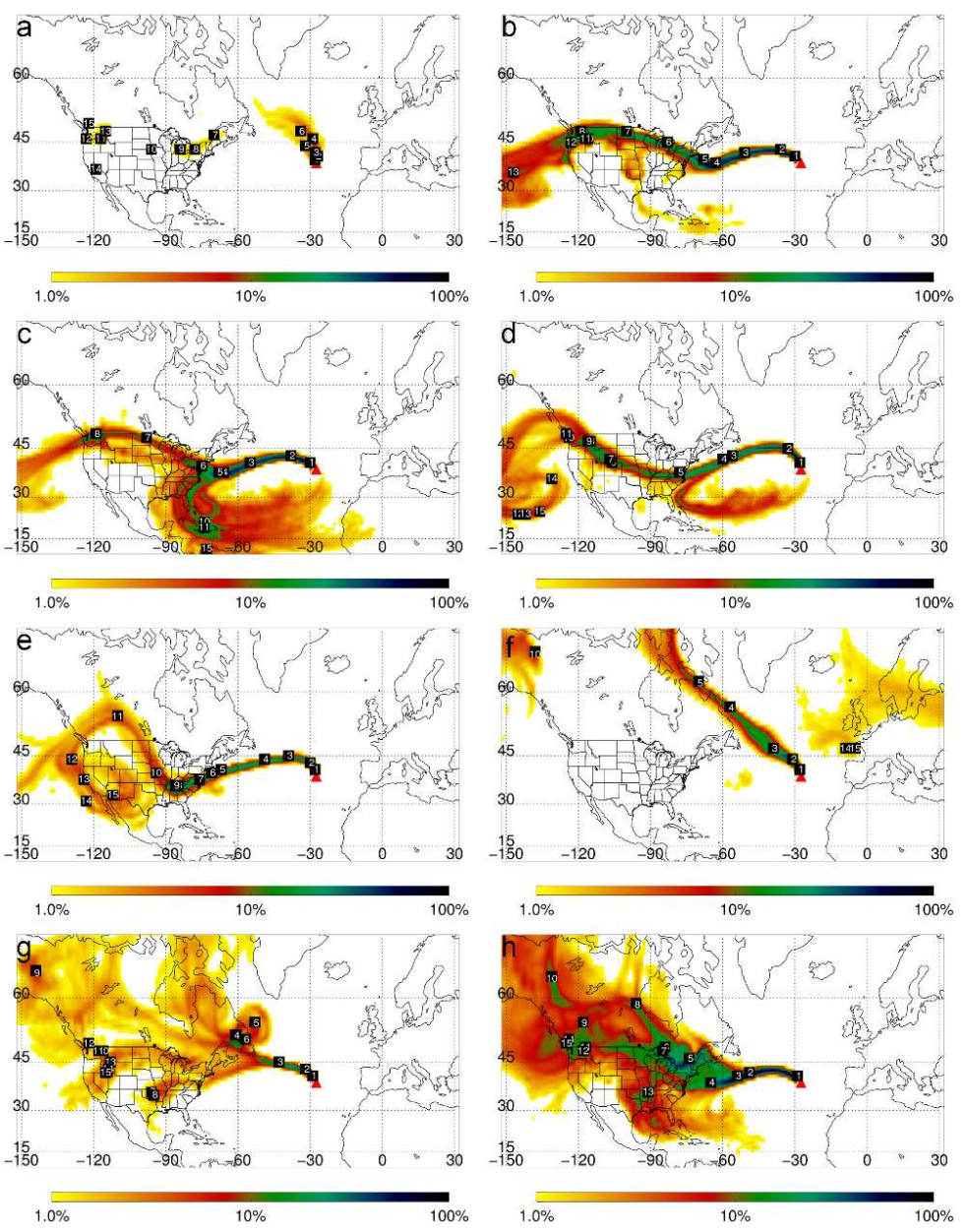

Figure 1. Column-integrated residence time over the 20-day transport time retrieved from FLEXPART retroplumes for 2017. (a) S3-1, (b) S3-2, (c) S3-3, (d) S3-4, (e) S4-1, (f) S4-2, (g) S4-3, (h) S4-4. The vertical distribution of the retroplumes residence time at given upwind times are shown in Fig. S5. 


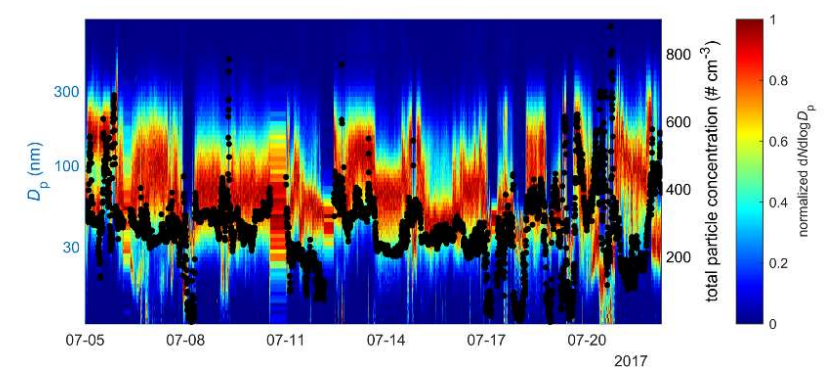

Figure 2. Normalized particle size distribution measured (left y-axis, color map) and total particle concentration from

10 to $800 \mathrm{~nm}$ (right y-axis, solid black cycles) from 05 July 2017 to 21 July 2017. 

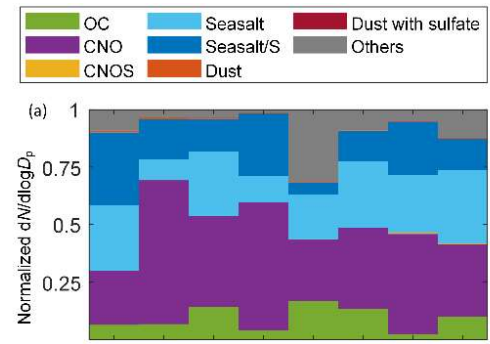

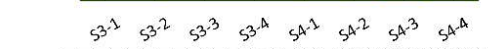

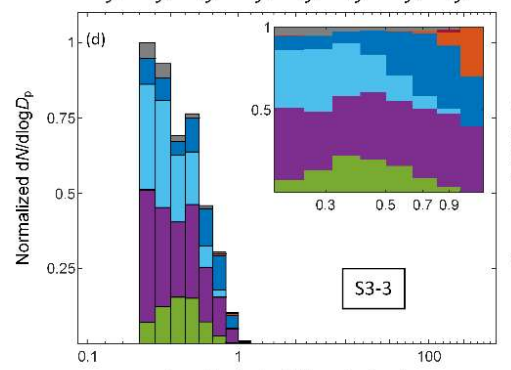

Area Equivalent Diameter $(\mu \mathrm{m})$

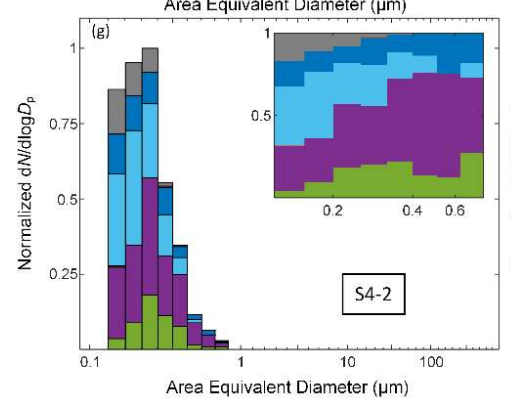

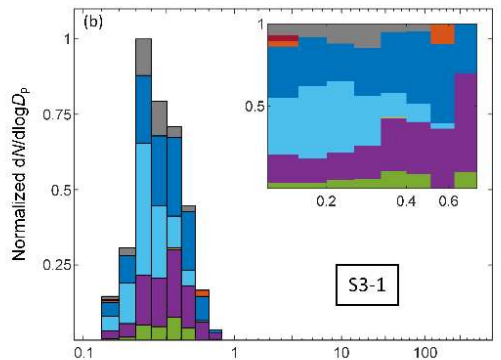
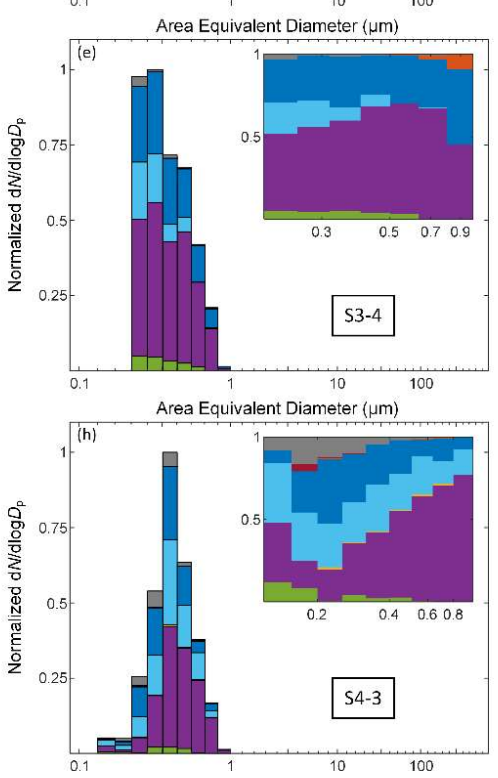

Area Equivalent Diameter $(\mu \mathrm{m})$
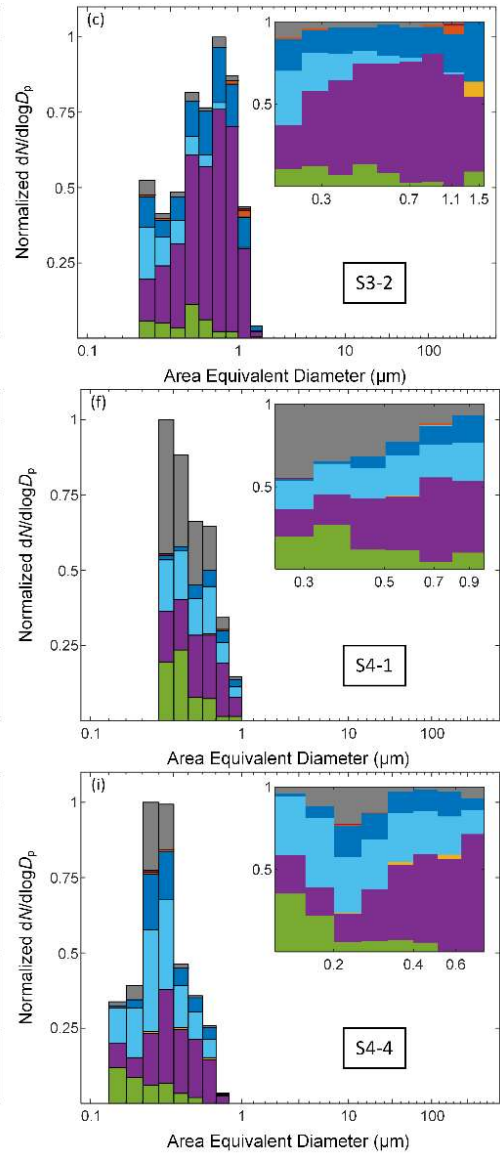

Figure 3. Chemically resolved size distributions inferred from the CCSEM-EDX data for 2017. (a) Fraction of different 


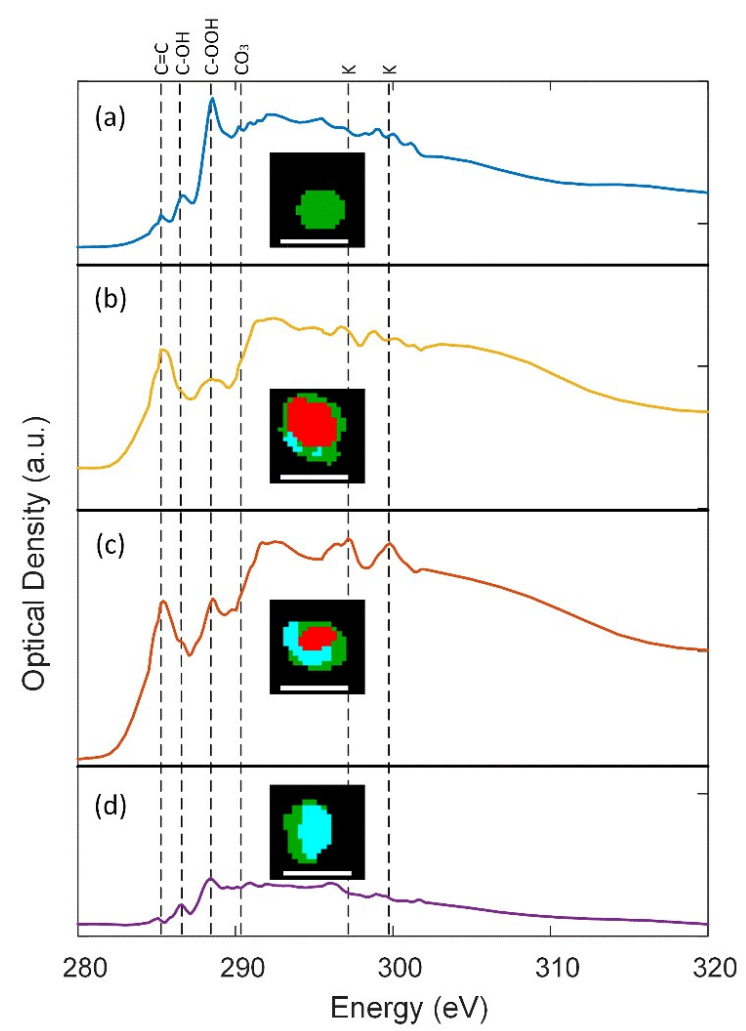

Figure 4. Representative STXM/NEXAFS spectra of (a) organic particle (green), (b) EC core (red) coated by OC (green), (c) internally mixed elemental carbon (red), and IN (blue) core coated by OC (green), and (d) IN (blue) core coated by OC (green). White scale bars represent $500 \mathrm{~nm}$. 

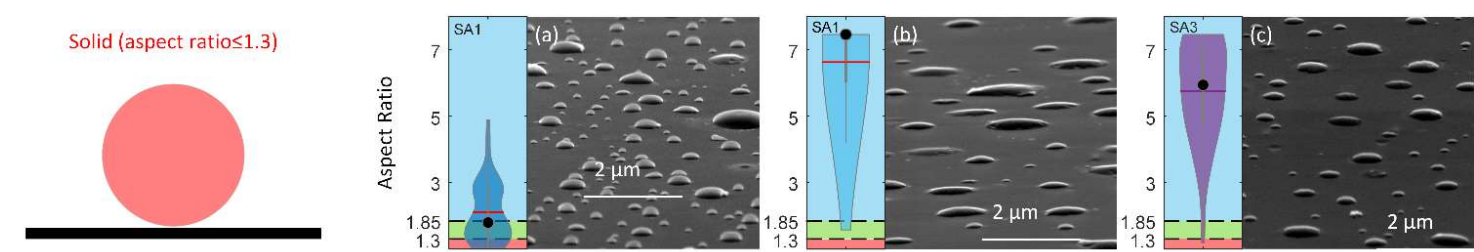

Semisolid (1.3<aspect ratio $\leq 1.85)$
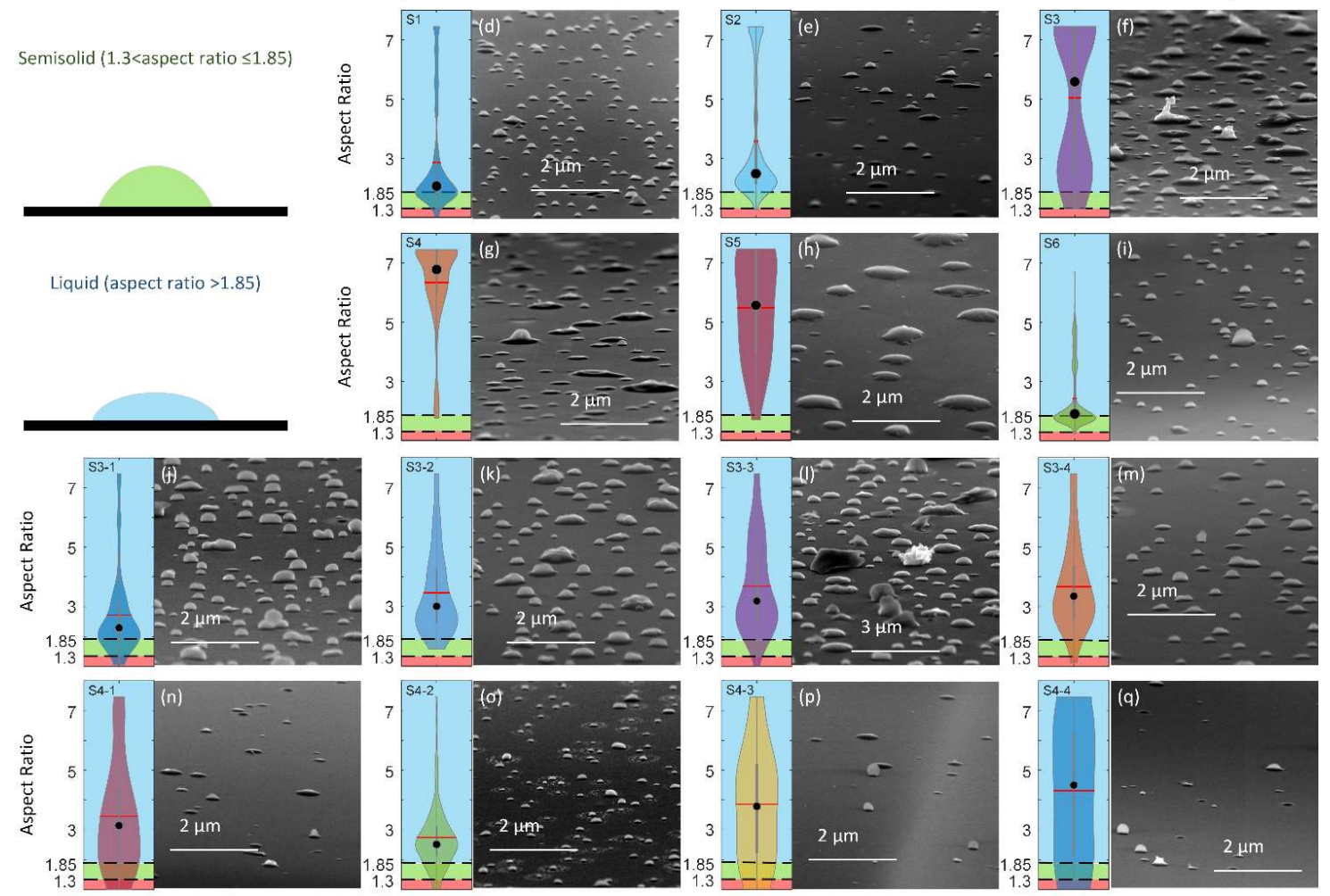

Figure 5. Violin plots of 'corrected' aspect ratio (left) and typical tilted images (right) of Pico 2017 (a to h), Pico 2014 (i to k), and Pico 2015 (l to p). The shaded region corresponds to the different phase states (red: solid state; green: semisolid state; blue: liquid state). The red lines indicate the means, and the black dots the medians. 
https://doi.org/10.5194/acp-2022-84

Preprint. Discussion started: 11 February 2022

(c) Author(s) 2022. CC BY 4.0 License.
Atmospheric

Chemistry and Physics

Discussions
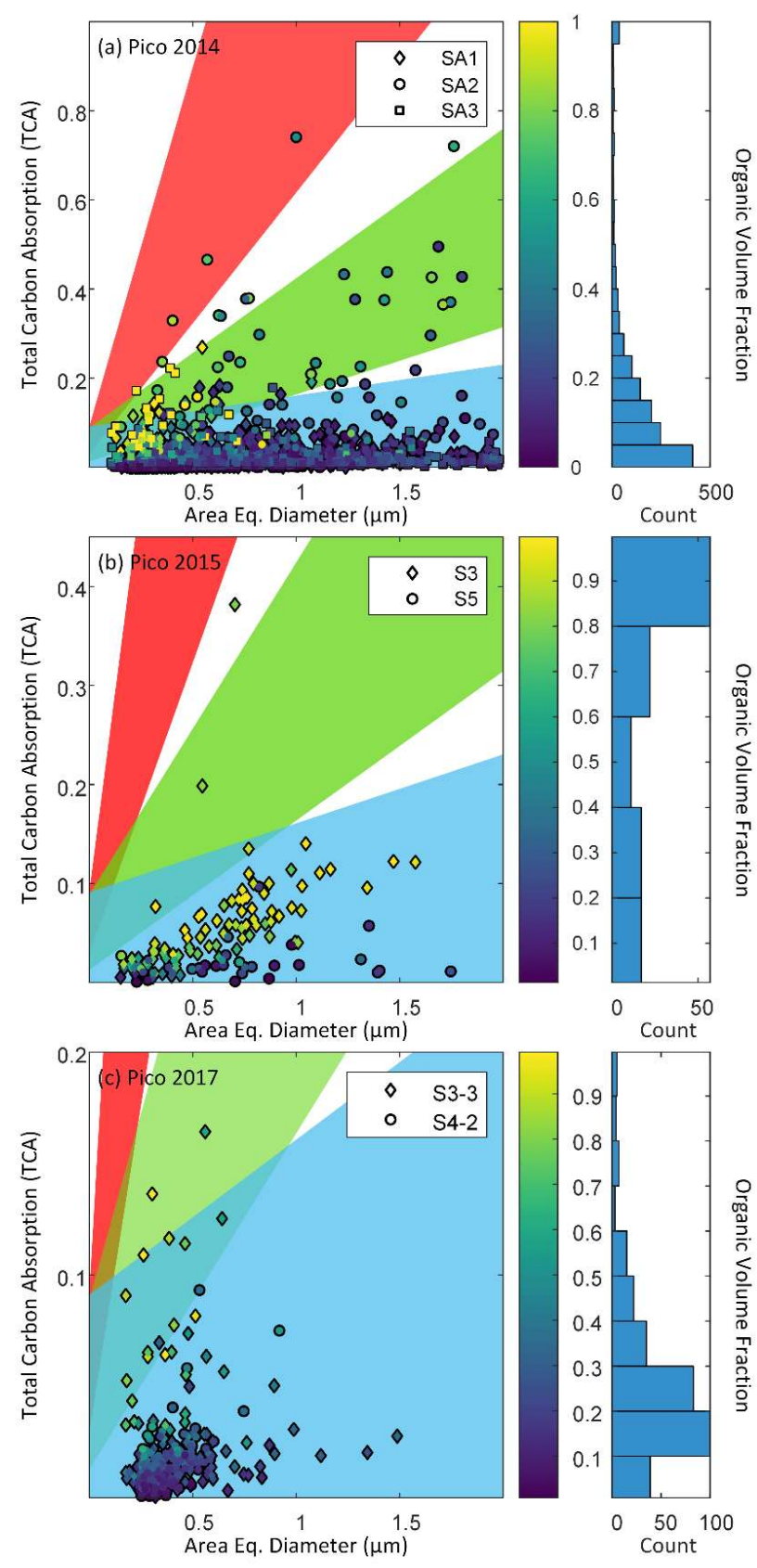

950 
https://doi.org/10.5194/acp-2022-84

Preprint. Discussion started: 11 February 2022

(C) Author(s) 2022. CC BY 4.0 License.

(c) (i)

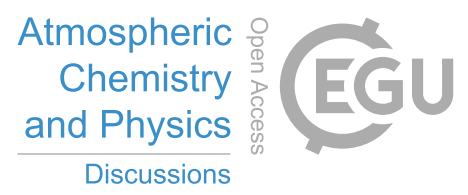

Figure 6. Total carbon absorption (TCA) as a function of area equivalent diameter of the impacted particles (a) and histogram plot of TCA from (a) Pico 2014, (b) Pico 2015, and (c) Pico 2017. Symbols are colored by their organic volume fraction retrieved from STXM-NEXAFS measurements. Shaded areas represent different phase state regions (liquid: blue, semisolid: green, and solid: red). Side plots are histograms of the organic volume fraction. 